\title{
Terms for Vessels in Arabic and Coptic Documentary Texts and Their Archaeological and Ethnographic Correlates
}

\author{
Tasha Vorderstrasse
}

\section{Introduction}

Both papyri and material remains provide insights into the consumption and construction of pottery in early Islamic Egypt by various members and groups of the population. This paper will focus on terms for jars in Arabic and Coptic documentary papyri in the early Islamic period (7th-1oth centuries) and their possible archaeological correlates in pottery, metal, glass, and parchment. There have been previous attempts to link jar terms, particularly in Greek papyri (and occasionally in Coptic) with actual objects, but the Arabic evidence has remained largely unstudied in this regard. Archaeologists, however, have tried to link pottery from all periods found in their Egyptian excavations with ethnographic examples and to provide the pottery with Arabic names that come from nineteenth-and twentieth-century pottery.

This paper will try to remedy this by offering a comparison of actual objects with contemporary Arabic and Coptic names for vessels in order to better understand consumption patterns in the early Islamic period in Egypt. First, the archaeological evidence for different types of jars and containers from early Islamic Egypt will be examined. Then the papyrological evidence will be compared with the ethnographic attestations of jars. Early Islamic period Arabic papyrological terms for jars will subsequently be discussed in detail, including, where it is possible to determine, the types of material from which these jars were manufactured and what types of objects they contained. Finally, the Arabic, Coptic-Arabic, and Coptic papyrological and ethnographic evidence will be combined in order to provide possible names for the archaeological objects.

\section{Archaeological Evidence for Vessels}

When one begins to examine vessels from early Islamic Egypt, one is presented with a bewildering array of different forms, types, and materials, scattered

(C) TASHA VORDERSTRASSE, 2015 | DOI:10.1163/9789004284340_012

This is an open access chapter distributed under the terms of the prevailing CC-BY-NC License at the time of publication. 
through a variety of publications in different languages. The types of jars that will be examined here are storage jars, as the references in papyri are generally to these kind of containers which are either being sent by the writers of the documents or being received by them. This limits the research to vessels that were sealed in some way and excludes therefore wide mouthed jars. The vessels could be made from different types of materials including pottery, glass, metal, and parchment. The vessels contained different types of goods (both edible and non-edible) and were shipped in boats ${ }^{1}$ and by pack animals ${ }^{2}$ to their destination. Sturdier vessels were tied with rope to attach them to saddles of pack animals, while more fragile items were carefully packed in cloth sacks or baskets. ${ }^{3}$ References in the Coptic ostraca to "camels of wine," "camels of dates" and "camels of wheat" suggest that items were transported in sacks that weighed very little. ${ }^{4}$

The most common type of jar used in the early Islamic period was made of the clay amphora. The ubiquity of amphorae in the early Islamic period is not surprising, since they had been the primary transport jars used throughout the Hellenistic, Roman, and Byzantine periods. Their use simply continued in the early Islamic period. Amphorae could contain a wide variety of liquid, semi-liquid, and solid objects, including grain, olive oil, wine, garum, cheese, and honey, which were transported on a wide scale throughout the Mediterranean. The majority of the goods shipped in the amphorae have not survived in the archaeological record, although there is some evidence of oil residue, grape seeds, and pitched interiors. Determining the contents of these vessels remains a challenge for archaeologists. Trace analysis has been applied to some vessels, particularly to amphorae. It has usually been assumed that if an interior of a pottery vessel is pitched, it would have contained wine or wine vinegar, while non-pitched vessels would contain other liquids such as olive oil or dry

1 For depictions of boats carrying amphorae from early Byzantine Syria and Palestine, see Decker, Food 77, fig. 4.5; Kingsley, The economic impact 52, 61, no. 48.

2 Cohen, Kissufim 255.

3 For an example of this type of packing, see Petrie Museum UC65051, two glass bottles wrapped in textile. For the difficulties in shipping these types of objects see, for example, O.Mon.Claud. 128-129 (early 2nd century C.E.) In the first ostracon the writer asks for baskets to protect water skins. Apparently he did not get them as he explains in the next letter that the skins have become useless. In P.Oxy. 1294 (late 2nd/early yrd century CE) the writer asks for a bread basket with a lock that contained four flasks. Shipping objects was not without a certain amount of risk, however. Individuals could and did injure themselves when loading full wine amphorae (Mango, Beyond 96).

4 Heurtel, Écrits 143-144. 
goods, such as cereals. ${ }^{5}$ As the tests from Fusțatt have indicated, however, it is dangerous to assume that pitched amphorae always contained wine. It is clear that pitched amphorae could in fact also contain other liquids such as oil, sauces, honey, fish, or cheese. ${ }^{6}$ In general, the papyrological evidence from the Hellenistic-Islamic periods suggests a large variety of commodities that were transported in amphorae in Egypt. ${ }^{7}$

It is clear from the texts that orders for jars were either in bulk or small quantities. The choice between these two options clearly depended on what the individual was planning to use the jar(s) for. Individuals who were involved in the production of liquid or solid goods that would be transported in vessels would often order these containers in bulk. In O.EdfouIFAO 107, which dates to the seventh century, for example, a potter promises to deliver 2070 jars (Koүфon from Greek $x \circ \hat{\phi} \phi \alpha$ ) without default. The word used for jar in this instance means empty and this is a term that is used by transporters to refer to the delivery of jars that were not filled with any goods. Often the delivery of jars was by the thousands or at least hundreds although sometimes the numbers were smaller. ${ }^{8}$ In the first part of the eighth century the correspondence of the west-Theban anchorite Frange provides interesting details about the ordering of containers that may have been fairly typical of individuals purchasing jars for their own use. In this case Frange is ordering a jar that is essentially made to order for him. In text no. 53, he asks an intermediary to order him a jar (кळтюN, see discussion below) and demands that it should be of good quality, that it should have a thick base (at the end of the text he reiterates that he wants a large base) and that the two handles should be fitted securely. ${ }^{9}$

5 Peacock and Williams, Amphorae 2, 31; Greene, The archaeology 162; Curtis, Garum and Salsamenta 35, 39; Bailey, Gaza jars 295-296; Whitbread, Greek transport 19; van Alfen, New light 203, 208; Formenti and Duthel, The analysis 84; Blakely, Ceramics 38; Alcock, Food 14, 83, 86-87; Decker, Food 76, 80; Ballet, Un atelier d' amphore 363-364; Kingsley, The economic impact 51; Mayerson, Pitch.

6 Vogt et al, Notes 76 .

7 Curtis, Garum and Salsamenta 134-136; Chouliara-Raïos, L'abeille 74; Kruit and Worp, Geographical 98, 107-108; Mayerson, Radish oil 109, 113, 117.

8 Diethart, Neue papyri 80; Mayerson, A note; Mayerson, The knidion 166, no. 1; Mayerson, Enigmatic; Bacot, Le vin 719; Bacot, Ostraca 10, 144 (Diethart is incorrectly cited here as Palme, whose article on corrections to Edfu ostraca appears in the same volume and is also used by this author). For attestations in Coptic, see Förster, Wörterbuch 440-441.

9 O.Frangé 10. For the dating of the texts, see Boud'hors and Heurtel, Les ostraca coptes 70-71. In another text Frange orders a small limestone 6at made for him to place a jar on (O.Frangé 113, notes on no. 120.22-32). For a discussion of Islamic stone jar stands, see Knauer Marble. The jar stands discussed in this article are elaborately decorated and made of marble, with a 
In the early Byzantine period, the ubiquitous LRA1 amphorae were produced in Syria, Cyprus, Cilicia and elsewhere along the Turkish coast. ${ }^{10}$ They have been found in large numbers throughout Egypt and the rest of the Mediterranean, ${ }^{11}$ while imitation LRA1 amphorae were also produced in Egypt. ${ }^{12}$ This amphora had a cylindrical form with a capacity of between 16.54 and 26.44 liters. ${ }^{13}$ The current archaeological evidence indicates that LRA1 amphorae disappeared in Egypt during the course of the seventh century, particularly during the second part of the seventh century after the Islamic conquest. ${ }^{14}$ The use of these amphorae seems to have continued, however, at least in a limited way, into the eighth century in Syria-Palestine. ${ }^{15}$ Imitation LRA1 amphorae continued to be produced in Egypt, presumably to fill the gap left by the decrease in import, into the eighth century. Again, however, the production centers were limited. Such imitation amphorae have been found in late seventh/eighthcentury contexts at Kellia, Saqqara (where the excavator dates it no later than the seventh century), Tod (dated to mid-8th/9th centuries), and Deir el-Naqlun as well as the Sinai. ${ }^{16}$ Another popular type of amphorae in the early Byzantine

basin that allowed the water filtering through the jars to be collected and used later. Knauer also discusses some other jar stands, including some that are simpler than the Islamic ones, which she describes as being Coptic (Knauer, Marble 91-93). Empereur and Picon, Les régions 224-225, 231-232, 236-243; van Alfen, New light 210; Decker, Food 76-78; Manning et al, Late Roman 233-258; Opait, On the origin. There are numerous sites where LRA1 amphorae are found and a few examples are given here: Egloff, Kellia 111; Ballet and Picon, Recherches 23; Gempeler, Elephantine X 52; Engemann, À propos 154; Ghaly, Pottery 168, 170; Majcherek, Roman amphorae 217; Bailey, Marsa Matruh 80; Hayes, The pottery 121; Heidorn, Pottery 39; Tomber, Pottery 244; Gascoigne, Amphorae 164; Lecuyot, Amphores 377, 380-381. For discussion of the distribution of LRA1 in general, see Decker, Food, 76-77.

12 Ghaly, Pottery 168, 170; Bailey, Excavations 122; Dixneuf, Amphores 136, 174-175.

13 Decker, Food 76.

14 Egloff, Kellia 110, 114-115; Górecki, Deir el-Naqlun 58-59; Gempeler, Elephantine x no. 198; Sidebotham, Bernard, and Pyke, Late Roman 215; Vogt, Les céramiques 257; Guidotti and Pesi, La ceramica 33 (dates the LRAl amphorae to the 6 th $/ 7$ th century but is not more specific); Marchand and Dixneuf, Amphores 319; Dixneuf, Amphores 174-175. The picture may, however, be more complex. See Majcherek, Alexandria's 235 who states that the LRA1 amphora imports continued into the early Islamic period at Alexandria and were stable from the end of the Byzantine period (although he does not give an exact date) and Rousset and Marchand, Secteur nord 409 and Marchand and Dixneuf, Amphores 319 who state that the number of amphorae drops considerably between the first and the second half of the seventh century at Tebtunis and Bawit.

15 Orssaud, De passage 197.

16 Ghaly, Pottery 168, 171; Bonnet 1994, 363; Godlewski, Derda, and Górecki, Deir el Naqlun 
period was the LRA4, the so-called Gaza/Ashkelon amphora (see below), which is common at sites in Egypt. This type of amphora is cylindrical in shape and had a liquid capacity of between 16 and 26.5 liters. According to Kingsley, it is only produced in southern Palestine but it enjoyed a large circulation throughout the Mediterranean. ${ }^{17}$ The date when this form of amphorae stopped being produced is still unclear but its production seems to extend into the eighth century. ${ }^{18}$ Therefore, while the chronology of these amphorae remains to be studied in more detail, the use of the vessels does seem to extend into the early Islamic period but to disappear from Egyptian sites in the course of the seventh century, much as LRA1 amphorae. ${ }^{19}$

One of the most common amphorae found in the early Islamic period are of the LRA7 type. These amphorae were made in different parts of Egypt from the seventh to the eleventh centuries and are found throughout Egypt at sites such as Tebtunis, Dayr al-Bahrī, Fusțāt, Tod, Bawit, and Alexandria. This type of amphora has a spindly form that is only $10 \mathrm{~cm}$ in width and $60-70 \mathrm{~cm}$ in length. It is 7 to 8 liters in volume, considerably smaller than the other amphorae, and is often pitched on the inside. Archaeologists have suggested, based upon their shape, that the amphorae were probably meant to transport a fluid such as wine, oil, or garum. When such amphorae from Fusțāt were tested to determine their contents, however, they turned out to have contained fat, although a vine branch was found embedded in the resin. At Kellia, an LRA7 amphora was found containing fish bones. These might of course have been wine amphorae that were re-used, ${ }^{20}$ but this is not clear.

Another type of amphora found commonly in Egypt is LRA5/6. These are the so-called baggy amphorae which date from between the seventh and twelfth centuries (continuing from earlier types). The amphorae are found primarily in

232, 256 (Figs. 21.2-3); Ballet, La céramique 164; Ballet, 'Uyûn Mûsâ 622-624; Marchand and Dixneuf, Amphores 316; Dixneuf, Amphores 178-179.

17 Kingsley, The economic 49, 53.

18 Egloff, Kellia 117; Bailey, Excavations 123-124.

19 Majcherek, Alexandria's 235; Marchand and Dixneuf, Amphores 310.

20 Górecki, Deir el-Naqlun 56, 61, 64; Vogt, Les céramiques 258-259; Rousset and Marchand with Laisney and Robert, Tebtynis 185-262, 206; Rousset and Marchand, Secteur nord 409; Rousset and Marchand, Secteur nord 2000 424, fig. 14.s-t, 435, 445, 458, fig. 40c and 46o, fig. 420; Vogt et al, Notes 241, 65-80. 66-67, 76; Ballet and Dixneuf, Ateliers d' amphores 72; Lecuyot and Pierrat-Bonnefois, Corpus 166, no. 87-88; Bavay, Les amphores 391-393; Gascoigne, Amphorae 166; Marangou and Marchand, Conteneurs 269-270; Marchand, Les amphores 176, 179; Marchand and Dixneuf, Amphores 312-314; Wilson and Grigoropoulos, The west 283; Simony, Étude 178; Dixneuf, Amphores 154-173 (with a list of find spots in Egypt). 
Lower Egypt and the Fayyūm (Abu Mina, Tebtunis, Tod, Kellia, Fusțāt, Alexandria, and Pelusium), although they are also found in Upper Egypt, at Elephantine and Ashmūnayn for example and in Middle Egypt at Amarna. In addition, they are found in Palestine including in Jerusalem, Khirbet al-Mafjar, Nessana, and Usais. The amphorae can be divided into two types: those made in Palestine and those made in Egypt. ${ }^{21}$ Indeed, archaeologists working in Palestine have argued that the Egyptians imitated these amphorae because they hoped to profit from the reputation of the Palestinian goods, particularly wine, ${ }^{22}$ often transported in the amphorae. On the other hand, because they do not have resin coating on the inside it has been argued that they probably were not used to transport wine. ${ }^{23}$ The popularity of imitated LRA $5 / 6$ and LRA1 in this period may explain why fewer imported LRA1 and LRA4 were found in Egypt after the Islamic conquest. ${ }^{24}$ Also in a later period amphorae produced in Egypt imitating the LRA2 type that date from the ninth to the twelfth centuries were far more popular than the imported LRA2 types. ${ }^{25}$

In addition to the more common amphorae that would have been used to transport goods over large distances and which were not all made in Egypt, there are also other amphorae (some of which were quite small), flasks, and jars. ${ }^{26}$ These types seem to have had a far more local distribution and were, in fact, probably all produced in Egypt. At virtually every site such storage jars have been found that would have been produced and traded throughout the local area or even within Egypt at large. These include the ovoid amphorae (6th-8th centuries) and small amphorae (mid 7th-mid 8th centuries) found at Tod. ${ }^{27}$ Other amphorae are only found at Kellia (mid 7th-mid 8th centu-

21 Ballet, Un atelier 355, 357, 361; Rousset and Marchand with Laisney and Robert, Tebtynis 397; Gempeler, Elephantine X K766 200; Egloff, Kellia 117-118; Orssaud, De passage 198; Bonnet, Le matériel 365-372; Vogt, Les céramiques 257-258; Bailey, Excavations 123, 136-137; Kingsley, The economic impact 5o; Majcherek, Alexandria's 61, 63; Ballet, La céramique 142, 206; Lecuyot and Pierrat-Bonnefois, Corpus 176, no. 131; Majcherek, Alexandria's 235; Faiers, A corpus 174, no. 438; Mouny, Note 632-633, pl. 1(4); Ballet, Un atelier; Gascoigne, Amphorae 166; Marangou and Marchand, Conteneurs 269; Marchand, Les amphores 176, 179; Marchand and Dixneuf, Amphores 316-317; Wilson and Grigoropoulos, The eest 283; Dixneuf, Amphores 142-153 (with a list of find spots in Egypt).

22 Kingsley, The economic impact 57.

23 Ballet, Un atelier $363-364$.

24 Ballet, De l'Égypte $35^{-37}$.

25 Górecki, Deir el-Naqlun 61, 64; Bailey, Excavations 122; Ballet, De l'Égypte 37; Majcherek, Alexandria's 61, 63.

26 Egloff, Kellia 119, 128-129.

27 Lecuyot and Pierrat-Bonnefois, Corpus 175, no. 122-123. 
ries), ${ }^{28}$ and jars are found at Tebtunis. ${ }^{29}$ Some of these smaller jars have a local distribution such as the spheroid amphorae which have been found at Kellia and Abu Mina and which date to the end of the seventh/beginning of the eighth century. ${ }^{30}$ This is also true of other flasks and jars, which would also have been used to store and send objects probably at a local level. Nevertheless, it is clear that the producers of these small jars, flasks, and amphorae were the same potters as those who made the LRA5/6 amphorae. ${ }^{31}$ There were also Aswan amphorae that were found primarily in the Syene region and further south dating to between the middle of the sixth and the middle of the eighth centuries. They are also common in Nubia, but rarely found north of Aswan, except at a few sites in Middle Egypt such as Esna, Tod, and Ashmūnayn. Despite the fact that the amphorae are not common north of Aswan, imitations were nonetheless produced, probably at Edfu which have been found at Thebes. Again the reason for imitating these amphorae seems to have been their association with the wines of Syene, which had a good reputation. ${ }^{32}$

In addition, there is one type which is not only extremely long-lived (the earliest examples date to either the late pharaonic or Ptolemaic period) but which is found at a variety of sites. This is the horizontal pilgrim jar which is asymmetric and has a short neck. It was found in Armant and was identified by the archaeologists as being a water vessel adapted to be slung on each side of a donkey. ${ }^{33}$ This type of pottery was also found at Dakhla dating to the Islamic period, where it is also identified as a water jar. ${ }^{34}$ The jars have also been found in Upper Egypt at Tod (dated to the 11th-12th centuries or

28 Egloff, Kellia 117 .

29 Rousset and Marchand with Laisney and Robert, Tebtynis fig. $42 \mathrm{~m}-0,458$, fig. $40 \mathrm{c}$ and 460 , fig. 420; Lecuyot and Pierrat-Bonnefois, Corpus 175, no. 124.

30 Egloff, Kellia 117-118. Interestingly, Egloff reports that a similar amphora was found in Jerusalem.

31 Rousset and Marchand with Laisney and Robert, Tebtynis 409.

32 Jacquet-Gordon, Ceramique et objets 6, pl. cxc; Ballet, Mahmoud, Vichy and Picon, Artisanat de la céramique, 140-141; Pierrat, Essai 187, fig. 59; Gempler, Elephantine $X$ 191, Abb. 121, 12-122, 1-5, Taf. 38,6; Bailey, Excavations 136, pl. 85; Lecuyot and PierratBonnefois, Corpus 199, no. 227; Aston, Amphorae 432; Bavay, Les Amorphes 394-395, fig. 59 .

33 Mond and Meyers, The Bucheum 82, pl. LXIv. go. See Class 9o. See also Aston, Amphorae 441; Ballet, Les amphores 482; Marchand, Les conteneurs 491-492, 495.

34 Hope, Dakhleh $235^{-236}$. See also Ashton, Comparative. The surface survey also revealed Roman examples. 
later), ${ }^{35}$ but also on the Red Sea coast at Quṣayr al-Qadīm, ${ }^{36}$ and in south Arabia. ${ }^{37}$

Unlike the other pottery jars found, this type of jar is still made today at the Dakhla Oasis. ${ }^{38}$ The early twentieth-century researchers, Mond and Meyers, found that the potters claimed they made Roman rather than Arab pottery when referring to the asymmetric water jars. The researchers also concluded: "In passing it may be remarked that this tendency has great advantages as the old conservative idea for cleanliness has been preserved there in face of the Arab and Turkish invasions." 39 Later twentieth-century observers suggested that hygiene might not have been the main aim as the jars are primarily used for carrying and short-term storage of water which may also have been the function of the jar in antiquity. In addition, the jars might have been used in order to store or transport wine. ${ }^{40}$ It has also been suggested that they may have contained different types of agricultural products including wine, wheat, barley, dates, olive oil, and castor oil. At the site of 'Ayn Manawir, located in the Dakhla Oasis, the excavators found castor bean seeds in the excavations and also mentioned in the Demotic ostraca ${ }^{41}$ The modern examples from Dakhla that are preserved in the Petrie Museum include undecorated forms and two smaller painted versions which may have been produced for a specific purpose or specific function. ${ }^{42}$

In contrast to pottery, glass does not always survive well in the archaeological record, particularly not in large fragments. Glass is commonly found at archaeological sites but usually in small fragments, which makes such a reconstruction difficult. Further complicating the matter is the fact that glass is not always published in detail. This means that it is difficult to assess the types of glass storage jars that would have been used in the early Islamic period. The main publication is Scanlon and Pinder-Wilson's book on Islamic glass from Fustāțt, ${ }^{43}$ but some glass bottles have also been published from other sites. The finds pub-

35 Pieerat, Essai 174; Lecuyot and Pierrat-Bonnefois, Corpus 169, no. 97, 176, no. 132.

36 Johnson and Whitcomb, Pottery pls. $36 \mathrm{~h}$, $47 \mathrm{j}$ (suggests this was a water bottle); Whitcomb, Islamic pl. 5on-p.

37 Rougelle, Excavations 295-297, fig. 9/8-11.

38 Mond and Meyers, The Bucheum 82, pl. LXIV. 9o; Hope, Dakhleh 235-236; Henein, Poterie 120-125.

39 Mond and Meyers, The Bucheum 82, pl. LXIV. 90.

40 Hope, Dakhleh 235-236.

$41 \quad$ Marchand, Les conteneurs 491.

42 Ashton, Comparative.

43 Scanlon and Pinder-Wilson, Fustat. 
lished include a wide variety of glass bottles that could easily contain the types of materials noted in the papyri. The surviving glass bottles which have been found at Fustāt are not very large, however. ${ }^{44}$ Similarly, the two glass flasks, now in the Petrie Museum, from Oxyrhynchos that date to the early Islamic period are also rather small. These two flasks were found in a cloth bag presumably to protect the glass from being broken while being transported. ${ }^{45}$ Depictions and other finds of glass in situ show the different methods of protection, such as baskets and cloth bags. ${ }^{46} \mathrm{~A}$ mosaic and a painting, both from the 2nd century C.E. from Carthage, show glass bottles in baskets ${ }^{47}$ and a 4th-century CE jug preserved in a basket is now in the Corning Museum of Glass. ${ }^{48}$ The design of some miniature amphorae even mimicked the basketry that would have contained actual glass vessels. ${ }^{49}$ Another example of glass stored in a basket as well as goblet shaped baskets (one of which also contained its goblet) come from the grave assemblage of Thaïas from Antinoe and are now in the Louvre. ${ }^{50}$ The

44 Lamm, Taf. 3. 34-35; Scanlon and Pinder-Wilson, Fustat Figs. 11-13. Most of the surviving pieces are between 10 and $11 \mathrm{~cm}$ high. The exception to this is $13 \mathrm{~b}$, which is $18.5 \mathrm{~cm}$ high. A similar piece, 18.2 centimeters high, comes from Midum (Kröger, Islamische no. 10).

uc65051. The two dark green vessels were wrapped in textiles (http://www.petrie.ucl.ac .uk/index2.html).

46 Meredith, Evaluating 196, no. 17, who states that glass was typically transported in leather cases or basketry specifically produced for this purpose.

$47 \quad$ Foy and Nenna, Tout feu 114.

48 Corning Museum of Glass no. 77.1.3. See N.A., Recent Important no. 10. This glass is $25.2 \mathrm{~cm}$ in height.

49 Stern, Roman 154, no. 4, cat. no. 59 (first half of 1st century).

50 Foy and Nenna, Tout feu 115, nos. 136-137; Calament, La révélation 374; Bénazeth and van Strydonck, Carbone 52, 55, 57, fig. 5. The dating of this material is problematic as carbon 14 dates of the individual pieces from the assemblage are not in accordance with one another. Thaïas herself seems to have been buried in 660 , while it has been argued that some pieces are too early or too late to be part of the assemblage. The goblet in the small basket dates between the end of the seventh and the ninth century (Bénazeth and van Strydonck, Carbone 55,57). The current state of publication is somewhat confusing on these pieces. In Bénazeth and van Strydonck, Carbone, on the one hand, it is claimed that there are four small baskets and only one large goblet, while it is the other way around in Foy and Nenna (Tout feu 115, nos. 136-137). Calament, supporting the statement of Foy and Nenna, gives a list of the objects displayed with Thaïas in 1898 , which states that there were four goblet cases and two other baskets. Calament identifies the times mentioned in this list with four goblet shaped baskets and a basket containing a goblet in the Egyptian collection at the Louvre and notes a goblet shaped basket conserved at Rennes (Calament, La révélation 374). Gayet, on the other hand, describes six baskets and one other basket (which seems 
most important piece for reconstructing the transport of items of glass in this period, however, is a $32.2 \mathrm{~cm}$ high glass bottle found at Tebtunis which dates to the beginning of the tenth century. This bottle, like the LRA7 amphorae, is very spindly and therefore not very stable. The bottle is likely to have been used to transport liquids similar to those transported in amphorae. It has been suggested that this piece had a funerary aspect ${ }^{51}$ but this seems unlikely. It should be kept in mind, however, that not all glasses found in baskets were for transport. A second-century CE glass from the Fayyūm, found in a basket together with its lid, is said to be a funerary urn. ${ }^{22}$

In the papyri, there are a number of examples where jars are being shipped in baskets, although the jar's material is not clear. In some cases, it is merely stated that a "basket" of wine should be sent, which infers that there is a jar in basket. In other cases, however, the texts explicitly mention that the wine is to be sent in the baskets. ${ }^{53}$

The other main type of material used for transporting goods was metal. Metal is even more problematic to assess than glass, because it tends not to survive well and is often not published unless it is decorated. Therefore, one is far more dependent on museum collections. Most of the metal objects from Egypt are ewers or buckets and very little is known about metalwork in general dating from the early Islamic period. In addition to these objects, there are metal flasks that date from the seventh to the tenth centuries. ${ }^{54}$ It has been claimed that, after the Islamic conquest, Egyptian metalwork, which had been traded all over the Mediterranean even ending up in the Sutton Hoo treasure in England, declined drastically because the population was heavily taxed and was not in a position to offer fine metalwork. ${ }^{55}$ The metal bottles found in

to be the goblet shaped basket) (Gayet, Antinoë 53, engraving of goblet shaped basket 55, engraving of a basket containing goblet $5^{6}$ ).

$5^{1}$ Foy, Secteur nord 480-481. no. 151, Musée égyptien du Caire inv. J. 41879. Despite the fact that this piece is published in a study of the glass of the current Tebtunis excavations, it was found between 1909 and 1910.

$5^{2}$ Hassel, Glasamphore 908-999, Abb. 94.

53 Crum, A Coptic 777a; Crum, The monestary 75; Husselman, Coptic documents 68-69; Bacot, Du nouveau 158. The texts where this is clear are P.Mon.Epiph. 90, O.CrumST 132, and O.Crum 160.

Fehérvári, Islamic no. 2, 33-34, 41-42, 46, nos. 20-22; Baer, Metalwork 84-87, 90; Allen, Concave 132; von Gladiss and Kröger, Islamische no. 139; Allen, Metalwork 16-17; Ward, Islamic 42. The recent publication of bronze vessels from the Coptic museum mentions some small bronze bottles whose chronology was difficult to establish (Bénazeth, La vaisselle 103).

Ward, Islamic 42. 
the eastern Islamic empire in Sardis and Nishapur, but also in Syria provide an indication of the types of containers that could have been used in this period. The types seem to be long-lived, dating from the seventh to the eleventh centuries. Some of these bottles are described as being "amphoresque." 56

In addition to the flasks of other materials, there were parchment flasks, but their survival is very rare. One found at Tell Idfū excavations is a small flask with a straw grill covered with transparent parchment. ${ }^{57}$ This is an exceptional piece that would have probably transported something very light in weight. It may be a type that was far more common but simply has not survived well in the archaeological record.

\section{Papyrology and Ethnography}

The archaeological evidence shows that a wide variety of different types of storage jars made of different materials was in use amongst the inhabitants of early Islamic Egypt. It is therefore not surprising that the jars are frequently mentioned in documentary papyri recording Egyptians' daily life concerns and activities. There are a variety of names attested in Coptic and Arabic papyri and these can be compared to ethnographic works from nineteenth-and twentieth-century Egypt that record Arabic terms for jars. There have been attempts in the past to link the jars mentioned in the papyri with the jar names from nineteenth-and twentieth-century Egypt, ${ }^{58}$ and with archaeological and ethnographic terms, ${ }^{59}$ but there have been no attempts to join these three data sets making connections between the archaeological and Arabic papyrological terms. It has, however, been attempted for Greek papyri, with the study of jar names that are derived from geographical locations. Greek geographical jar names such as Rhodian and Gazan can indeed be linked to specific jar types. ${ }^{60}$

Even when it has been suggested that certain amphorae were identical to jars mentioned in the papyri, making exact correlates can be problematic. There is one instance, however, where it is possible to do so. The term "Aswan plate" appears in Coptic-Arabic and Coptic spells as well as written on a plate

\footnotetext{
56 Allen, Nishapur; Waldbaum 1983; Mango, Beyond fig. 5.7; Pitarakis 2005; Mango, Tracking Byzantine 230-231, fig. 15.5.

57 Henne, Rapport 9, 36

$5^{8}$ Karabacek. Papyrus Erzherzog; Lane, Manners 152, 155; Grohmann, From the world 10, fig. 1; Grohmann, Einführung 9, Abb. 2.

59 Bailey, Excavations 75.

6o Kruit and Worp, Geographical 65, 72-75, 98, 105, 107, 140.
} 
in the British Museum. ${ }^{61}$ The piece is described by Hall as being a "part of a moulded red-faced imitation Arrentine ware bowl." ${ }^{2}$ One of the spells, however, Inv. no. 515, mentions white Aswan bowls. ${ }^{63}$ The word used for the vessel is in this instance different from the word used in the other two texts. This makes it likely that a different type of bowl or plate is being referred to here. The qualification "white" added to "Aswan" might thus have referred to a specific type of vessel. ${ }^{64}$ The same term for plate also appears in Coptic texts elsewhere and it has been suggested that it is not an ordinary plate. ${ }^{65}$ It is clear from this example, however, that even when the identification between vessel and name seems to be straightforward, it is always more complicated. Furthermore, the texts generally do not tell us whether the objects are made from glass, ceramics, or metal, and only by looking at archaeology can it become clear what types of objects might be actually meant in the texts. ${ }^{66}$ All of this must be kept in mind when examining the terms for vessels. Both Arabic and Coptic terms will be considered here. There are far more Coptic terms known than Arabic ones, but this should not be considered surprising: far more Coptic ostraca and papyri have been published than Arabic texts. In addition to papyri, a considerable amount of information about consumption in the early Islamic period comes from the commodities listed on glass vessel stamps. Glass vessel stamps are known in Egypt in the Byzantine period, ${ }^{67}$ but are found in larger numbers in the early Islamic period. ${ }^{68}$ The glass stamps would have been applied to vessels while still hot and they have been found attached to several glass cups, including one from the American excavations at Fustātạ. ${ }^{69}$

61 See van der Vliet, Varia 224-225. The Arabic-Coptic bilingual spell and one Coptic spell are published in Bilabel and Grohmann, Griechische no. 123 (PSR Inv. no. 500/1), line 1 (Arabic), no.131 (PSR Inv. no. 518) line 19 (the reading is according to Bilabel and Grohmann somewhat uncertain, but they do restore it, although they do not translate it). Another Coptic spell is published in Stegemann, Neue Zauber 78, 1. 55-56 (PSR Inv. no. 518). The inscribed plate is published (with a drawing but no photo) in Hall 1905, pl. 38.1 (вM 27718). I would like to thank J. van der Vliet for the reference to his article.

$62 \quad$ Hall, Coptic pl. 38.1 (вм 27718).

63 White bowls, without the appellation "Aswan," also appear in a Coptic text now in Leiden.

64 Van der Vliet, Varia 224.

65 Bacot and Heurtel, Ostraca coptes 24.

66 Mossakowska-Gaubert, La verrerie 1443-1444.

67 Lane-Poole, Catalogue xviii-xix; Ross, Byzantine 83; Sams, The weighting 202-230, 210.

68 Bates, The function 63-92, 63-64; Bacharach, Introduction 5 . For glass stamps from outside of Egypt, see Morton, A catalogue 39; Heidemann, Katalog 195-196.

69 Scanlon and Pinder-Wilson, Fustat glass fig. 37. The glass would have been for dried plums. 
The glass vessel stamps give different types of information, including contents, measures, and weight and occasionally the name of the person who authorised the issue of these stamps. It used to be assumed that glass vessel stamps indicated commodities that would have been used in pharmaceuticals or even more general weights. ${ }^{70}$ There has been a growing understanding, however, that glass vessel stamps are likely to have indicated items consumed or used on a daily basis. The commodities include oil (olive oil, etc.), fat, dairy products (milk, cheese, clarified butter), lentils (black lentils and skinned lentils), spices (coriander, fenugreek, mustard, cumin), lupines, sesame, peaches or plums, honey, jujubes, palm fruit, cooked noodles, wine, beer, millet beer, henna, garlic, meat. ${ }^{71}$ This information can be combined with the information from the amphorae to see the wide variety of different food stuffs attested.

The amount that a vessel might hold is often difficult to determine. Even when there is information about this in texts, it is not always straightforward. The authors of the papyri did not specify weights; it is to the literary texts that one must turn in order to gain information about how much a particular vessel might have carried or how large a particular measure was. The authors of these texts, however, do not always agree, and it is clear that the contents, weight and size of measures differed per region. Even within Egypt, the size of a particular measure was not always the same. ${ }^{72}$ The differences were not only determined by where a particular measure came from but also by the type of liquid or dry goods that it was used for. Wine, oil, and honey all required different measures; an equal volume of honey has a greater weight than a similar amount of wine, while wine and oil are quite compatible. ${ }^{73}$

$70 \quad$ Lane-Poole, Catalogue, vii, xvii, xxii-xxiv; Miles, Contributions 384. This affects how Miles translated the names of particular commodities (Miles, Egyptian glass $384-389$ ). Balog, Umayyad 10, 12, 29; Eldada, Glass weights 113; Hamarneh and Awad, Glass vessel 168.

71 Miles, Contributions; Miles, Egyptian glass 386-387; Balog, Umayyad 30; Bacharach, Introduction 117, 147; Eldada, Glass weights 113, 117; Hamarneh and Awad, Glass vessel 167, 169-171, 174, no. 5 .

72 Sauvaire, On a treatise 291-292, 297-299; Rogers 1878, 98-112, 110; Sauvaire, Arabic metrology 253-284, 253-254, 256 .

73 Sauvaire, Arab metrology 495-524, 495. Ms. Madrid ms. arabe gg. 57. 


\section{Arabic Terms for Vessels}

There is a number of terms for vessels that appear in Arabic papyri, some of these words were borrowed from Coptic (possibly to describe vessels that the Arabs were not familiar with). ${ }^{74}$ One of the most common terms was jarra (جرة), which is attested in papyri dating to between the eighth and tenth centuries. Those papyri of which the find spots can be determined come from Medīnat al-Fayyūm (one example) and Edfu (two examples). The jarras are said to have contained a large variety of commodities such as honey, wine, sugar syrup, grape syrup, and water. ${ }^{75}$ David-Weill published a papyrus from the Louvre mentioning a jarra containing oil made, in his translation, from eggplant seeds. ${ }^{76}$ This seems an unlikely translation as not much oil can be extracted from eggplant grains. While the contents of the jarra are varied, this also held true for the size of a jarra. According to the literary sources, a jarra of Antioch held $23 \mathrm{~kg}$, a large jarra $11 \mathrm{~kg}$, and a small one $1.9 \mathrm{~kg} .{ }^{77}$ The term may also be attested in a Coptic text. Crum reports that in Bibliothèque Nationale ms. 55 there is mention of $+x$ (جرة (صاغرة). ( 1 var.). In Coptic, this appears to be хорвес, which Crum translates as a small (?) vessel. ${ }^{78}$ Again, there is no material specified, but the size suggests that the jarra was made of pottery and it could easily be connected with one of the amphorae found at the archaeological sites. Therefore, at least some jarra could be LRA7 or LRA 5/6 which is found so frequently at early Islamic sites and which seem to have been used for the same goods that the papyri mention in relation to the jarra. If small jarras are being referred to in the papyri, then they might be the small flasks, made from glass or metal, that have been found at archaeological sites. In illuminated manuscripts, vessels identified by jarra are drawn as two handled jars apparently made of metal. ${ }^{79}$

When one turns to the ethnographic attestations of the jarra, however, the picture is very different. The papyrological evidence suggests that the

74 It should be kept in mind, however, that amphorae have been found in Arabia. See, for example, Sedov, New archaeological 113-114.

75 Grohmann, From the world commentary on P.Cair.Arab. Iv 339.9; Grohmann, Einführung 1954, 170-171; Marrow, Two Arabic Inv. no. 36.2; Rāgib, Quatre papyrus III recto 8; P.Khalili I 7.3.6; P.Vind.Arab. I 4.7.

76 David-Weill, Papyrus arabes no. 12.

77 Grohmann, Einführung 170-171.

78 Crum, A Coptic 785 B.

79 Hill, The book 49, 54, 72, 78, 80, 82, 84, 88, 100, 113-114, 130 (Models 4, 7, 19-22, 32, 38-39, 46). 
jarra would be a rather large pottery jar used to transport liquids of all types. The ethnographic attestations of jarra, however, suggest that a jarra or jarrat al-mayya (Eg.) al-kabira is, in fact, the unusually shaped jar mentioned above that is still being produced at Dakhla. In Egyptian and Syrian/Jordanian colloquial a jarra is a clay water jar or pitcher. ${ }^{80}$ In Syria and Jordan jarra is also used in more general terms for a storage jar. ${ }^{81}$ Water jars which are known in some areas as jarra are called elsewhere in Egypt zir. ${ }^{82}$ The jarra in Egypt can also preserve cheese and the jarrat al-laban holds milk. ${ }^{83}$ Therefore, there seems to be two types of jarra in the nineteenth and twentieth centuries: unusually shaped flasks that hold water and cheese and milk jars. This suggests that the meaning of jarra has changed through time and that it has become a far more specific term than it was in the early Islamic period.

Another common term in the Arabic papyri is qist (قسط):; the term is derived from the Greek measure $\xi \dot{\varepsilon} \sigma \tau \eta \varsigma$ (coming to the Arabic either from Greek or from Egyptian via Coptic, where the term also occurs as the measure ксестнс, z, zecT, zеcтd, zеcтe, etc.). ${ }^{84}$ In Arabic, however, the term may refer either to a vessel or a measure, ${ }^{85}$ and it is difficult to determine which is meant. The term qist, after all, even when used as a measure, implies the use of a vessel to contain the object in question. The papyri mentioning qist date from between the eighth and tenth centuries and the find spots of most of the papyri cannot be determined, but where it has been established, they come from Arsinoe/Fayyūm. As for contents a variety of liquid and semi-liquid commodities have been determined: oil (olive, radish, linen, and sesame), honey, wine, vinegar, and butter. Many of the references in the papyri refer to parts of a qist, which could suggest that these refer to a measure rather than to a specific vessel. ${ }^{86}$ In glass vessel stamps, the commodities mentioned include liquids such as wine and olive oil. ${ }^{87}$

\footnotetext{
$80 \quad$ Hinds and Badawi, A dictionary 155 .

81 Mershen, Recent hand-made 76, n. 7; Taniguchi, Ethnoarchaeological 144.

82 Henein, Poterie 161, 163; Ashton, Comparative.

83 Henein, Poterie 161, 163; Ashton, Comparative

84 Miles, Egyptian glass 385 ; Kruit and Worp, Metrological notes 111 (who note there are over 1,000 Greek examples of the word used as a measure); Förster, Wörterbuch 555. Grohmann, however, thinks it came from Aramaic into Arabic (Grohmann, Einführung 167).

85 Grohmann, Einführung 167; Morton, A catalogue 31.

86 Grohmann, Einführung 167-170.

87 Morton, A catalogue 31 .
} 
In one instance, the qist is a bronze vessel, ${ }^{88}$ while in others it is made from glass. ${ }^{89}$ It is clear that there are a variety of sizes of qist. In P.Cair.B.E. inv. no. 326.4 there is a reference to a large qist (a term which also occurs in glass weights) and to a qist al-laytī. In the papyri, qisț are referred to as whole, half, quarter, and eighth. According to literary evidence a small qist was $1.19 \mathrm{~kg}$ and a large qist $2.4 \mathrm{~kg}$. On the basis of this information Grohmann suggested that one qist was equal to 1.4 liters while Miles interpreted it to be a pint in size. ${ }^{90}$ This could suggest that the qist was a relatively small-sized vessel, but the evidence makes clear that the qist measure was not fixed. Indeed, both small and large qists are attested. ${ }^{91}$ The side of a glass cup from the Metropolitan Museum of Art has been stamped with the words: qist wafi (full measure). The glass cup holds $5^{0}$ cubic centimeters, but this does not compare with the qists attested in the literature. It has been suggested that the glass measure must be incorrect and should have read half of a quarter of a qist $t$ as fractions of a qist are common in glass weights, ${ }^{92}$ but it seems more likely that in glass measures, as in the papyri, the size of a qist measure differed significantly.

Once again, when one attempts to find archaeological correlates to a qist, one is confronted with the possibility that it may refer to different vessels, in particular when it is used as a measure. The qist seems to have been much smaller than the jarra, referring to smaller pottery, glass, and metal vessels. It is interesting that the qist seems to have evolved from a measure to a term that meant both a measure and a vessel. In Coptic, this process also seems to have occurred. While almost all the references to the term in Coptic appear to be measures, there is one exception to this, O.Medin.Habu Copt 5.11, where a list of goods is given and the word oүzестнс appears. The editors do not comment on this, they merely translate it as xestes. In the context of the list, the meaning of the word appears to be for a vessel rather than a measure. ${ }^{93}$

In modern Egyptian Arabic a qist is used for a metal can (such as milk man's churn $)^{94}$ and an oil pitcher. ${ }^{95}$ Rogers, in his study of weights and measures,

\footnotetext{
88 Grohmann, Einführung 167.

89 Day, An Umayyad 259; Miles, Egyptian glass 385, 387-388.

90 Grohmann, Einführung 167-170; Hinz, Islamische 50; See Grohmann's commentary on P.Cair.Arab. IV 342; Miles, Egyptian glass 385; Balog, Umayyad 30.

$91 \quad$ Sauvaire, A treatise 113; Morton, A catalogue 31.

92 Day, An Umayyad 259; Miles, Egyptian glass 385, 387-388; Balog, Umayyad 31.

93 See, for example, P.Ryl.Copt. 238.41 is a list (8th century) that has a half xestes of or for oil

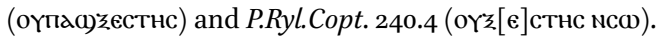

94 Hinds and Badawi, A dictionary 699.

95 Spiro, An Arabic-English 486.
} 
noted the presence of a qist on glass weights and made enquiries in Cairo about the object. He found evidence in 1878 for a vessel called an oil qist that was used to dip into oil jars (قسط الزيت), which did not have a specific size. He stated that the word was not used anymore for a fixed measure of capacity. ${ }^{96}$ Unlike other terms that appear in ethnographic studies, the qist is not a term that appears in separate pottery studies. This is probably due to the fact that by the nineteenth and twentieth centuries the term had come to refer to a metal vessel. The use of the term apparently changed through time, losing its meaning as a measure and becoming used exclusively to refer to a metal vessel.

The third common term in Arabic is the qulla (قلة), which, like qist, comes from a Coptic word, but in this instance not originally coming from Greek. The

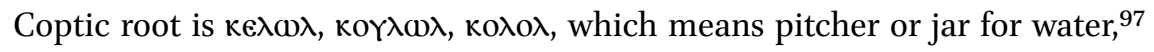
originally from hieroglyphic and known as krr in demotic. ${ }^{98}$ The term was

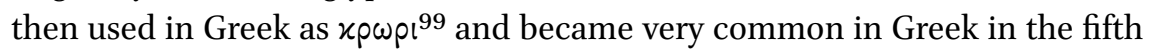
century CE and later (xovpl). ${ }^{100}$ Kruit and Worp suggest that it is equivalent to Greek/Coptic $x{ }^{\prime} \lambda \lambda \alpha \theta_{0},{ }^{101}$ but this is not the case. Despite the fact that qulla comes from the Coptic word kelal, it appears in several manuscripts as the equivalent to the Arabic words qist and $k \bar{u} z{ }^{102}$ which suggests that the authors of the papyri were not aware of the equivalence between the two terms.

The term is attested in Arabic texts dating from between the eighth and ninth centuries but no provenance for the papyri can be determined. The types of contents of this jar include liquid and semi-liquid contents: wine (including date wine), butter, cheese, molasses, raw sugar, oil (Palestinian olive oil and radish oil), soap, and black olives (which although being solid would have

$96 \quad$ Rogers, Unpublished glass 112.

97 Crum, A Coptic 104a. For some reason Alcock only gives the meaning "pitcher," although he does note its etymology, which is neglected by Crum (Alcock, Coptic terms 2). Another possible spelling in Coptic may be кoүגe as it appears in O. Frangé 253.9 referring to a jar. Boud'hors and Heurtel, Les ostraca suggest that this is perhaps the word $\kappa \epsilon \lambda \omega \lambda \kappa \circ \gamma \lambda \omega \lambda$ or $\kappa \lambda \in \kappa \in \lambda \mathrm{H}$ (Crum, A Coptic 102a) which is a vessel for liquids such as honey and oil.

98 Černý, Coptic 56 .

99 According to Bilabel, there is a papyrus that comes from the Hibeh cartonnage (Heidelberg 414) which contains a Greek Demotic glossary, with the Demotic written in Greek letters. Therefore: $\lambda \varepsilon \kappa \alpha \dot{\alpha} v o v-\varkappa p \omega \rho$ ( (Bilabel 1938, 79). Quecke suggests after a recent re-study of the papyrus that $\chi \omega \rho$ เ means $\tau(\dot{\alpha}) \lambda \alpha \nu \tau$ เov, talent (Quecke, Eine griechische-ägyptische 72-73).

$100 \quad$ Kruit and Worp, Metrological 110-111.

101 Kruit and Worp, Geographical 138.

102 Crum, A Coptic 104a. 
probably been stored in oil). Diem also suggested that one of the jars referred to in Grohmann's publication of PERF 769 may have held mixed pickles rather than the water that Grohmann suggested.

There are at least four sizes of qulla jars in the papyri: an ordinary qulla, which could be either a half or whole qulla, a large qulla, a small qulla, and a hip qulla. ${ }^{103}$ Although Grohmann assumed that the qulla was a large jar that would have stored $55 \mathrm{~kg},{ }^{104}$ the papyri show that there was a variety of different sizes. Further, a jarra is apparently smaller than a qulla because one qulla is said to have contained six jarra. ${ }^{105}$ In Coptic the term $\kappa \notin \lambda \omega \lambda$ is often found in lists of metal vessels etc., without any sort of object contained within it. ${ }^{106}$ The fact that Palestinian olive oil is attested in one of the papyri as being contained in the jar could argue for the idea that the qulla is actually the LRA $5 / 6$ which was produced in Palestine and Egypt and would have contained olive oil. ${ }^{107}$ If a jar was likely to be imported to Egypt containing olive oil, the chances that it was the LRA5/6 is quite high. The smaller version of the jar may be made from metal, as suggested by the Coptic variants. If Grohmann's hypothesis is correct the qulla might have been a very large storage jar, perhaps far larger than any of the amphorae.

The term qulla is known from a variety of ethnographic sources, already noted early on in Description de l'Égypte. Indeed, when Karabacek discusses PERF 710, he thinks that the qulla in the papyrus is the same as the one illustrated in Description de l'Égypte. ${ }^{108} \mathrm{He}$ did not discuss the correlation in great detail, however. Edward William Lane stated that the qulla was used in nineteenth-century Cairo as a water bottle and glass sherbet cup. ${ }^{109}$ This suggests that the term could refer to a wide variety of vessels both large and quite small. In Morocco it is thought to be an oil measure which in Casablanca contains $30 \mathrm{~kg}$ of oil and in Mazagan $17 \mathrm{~kg}$. This suggests oil would have been stored in a large jar in this period, perhaps not unlike the type seen by Lane in Cairo in the nineteenth century. ${ }^{110}$ Further, the term appears to have remained popular into the twentieth century, when it continued to mean a jar that contains

103 Grohmann, From the world 164; Grohmann, Einführung 171; P.Khalili I 3; P.Vind.Arab. I 16.5. Hip: P. Khalili I $7 \cdot 5$.

104 Grohmann, Einführung 171.

105 Grohmann, Einführung 171.

106 P.Ryl.Copt. 238.31; 242.4.

107 P.Berl.Arab. II 40.6.

108 Karabacek, Papyrus PERF 710.

109 Lane, Manners 155.

110 Grohman, Einführung 171. 
liquids, such as water. ${ }^{111}$ In Egyptian Arabic a qulla is an earthenware jug ${ }^{112}$ or a water bottle. ${ }^{113}$ Pots found in the Kellia excavations have been associated with the modern qulla, ${ }^{114}$ while other archaeoglogical material has also been connected to the ethnographic evidence of the qulla. ${ }^{115}$ Once again, there seems to be a change that has occurred between the attestations in the papyri and the ethnographic attestations. There are some qulla which seem to be quite large while others are very small.

In addition to these three fairly common terms for vessels in the Arabic papyri, there are two less common ones. One of these is the iqniz (إقنيز). The

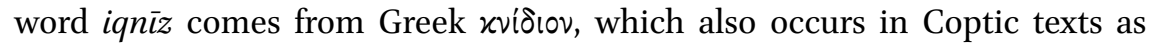

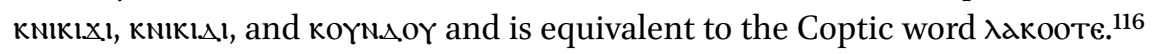
The term is very popular in both Greek and Coptic papyri, although it is rare in the Arabic papyri. Indeed, the term knidion is the most widely attested amphora name in the late antique period, although attestations first begin in the Ptolemaic period, then stop and begin again in the second century CE and continue into the ninth century. The Greek attestations of knidion jars indicate that it contained large amounts of wine and olive oil, but also other items such as honey, cheese, money, grapes, cheap wine or vinegar, mixed honey and wine, and honey and water drinks, garum, sweet olives, olives, pickles, and pickled calf meat. ${ }^{117}$ It has been argued that in the Byzantine period knidion jars ceased to be identified with a specific form or type, but rather referred generally to jar. This seems to be supported by the archaeological evidence as there are no imitation jars from Knidos produced in Egypt in the Byzantine period and in several Coptic texts knidion jars are equated with Coptic measures. ${ }^{118}$ Texts describe knidion jars to have been produced in Egypt. This suggests that the term continued to represent both the wine jar and a

111 Blackman, The fellahin 140; Mond and Meyers, The Bucheum 84; Brissaud, Les ateliers 217; Golvin, Thiriot, and Zakariya, Les potiers 27, no. 1, 28; Henein, Poterie 104, 154; Nicholson, Deir Mawas 142.

112 Hinds and Badawi, A Dictionary 716.

113 Spiro, An Arabic-English 500.

114 Henein, Poterie 104, 154. See also Ashton, Comparative.

115 Egloff, Kellia 128.

116 Bell, Metrology 22; Crum, A Coptic 111b; Grohmann, Einführung 170, no. 5; Černý, Coptic 59; Alcock, Coptic terms 1-2; Kruit and Worp, Geographical 72-75.

117 Clackson, Coptic 27, 157; Kruit and Worp, Geographical 104-105, 108; Mayerson, The knidion 165-166; Mayerson, Enigmatic knidion 205-209.

118 For Coptic measures, see Kruit and Worp, Geographical 72-75; Černý, Coptic 59; Alcock, Coptic terms 2. 
measure in the late Roman/Byzantine period, ${ }^{119}$ and presumably this would hold true for the early Islamic period as well. Whether or not the term knidion retained its geographical meaning in Coptic, it is clear that the term ceases to refer to an actual jar but rather becomes an extremely common wine measure in the early Islamic period. ${ }^{120}$ It was also used to measure other substances, such as pickles. ${ }^{121}$

In Arabic the term seems to refer to actual jars, rather than to a measure. This suggests that the term may be adapted from the Greek rather than the Coptic and hence it retained its original meaning. The Arabic texts date to between the seventh and eighth centuries and, where find spots can be determined, come from the Fayyūm and from Khirbat al-Mird in Palestine (one). The containers primarily contain liquids and semi-liquids such as wine (the most popular), but fat and soap are also attested. ${ }^{22}$ There is some evidence for the type of material that the objects were made of. The vessel from Khirbat al-Mird is made of bronze ${ }^{123}$ and Grohmann suggests that this is a small vessel, ${ }^{124}$ but there is no evidence for its actual size. The fact that it was in one instance made of metal suggests that metal was used in other instances too, although the carrying of liquid contents may also suggest amphorae.

The term does not survive in modern Egyptian Arabic and therefore is not attested in ethnographic studies or in dictionaries. This may have to do with the fact that it is a measure in Coptic and was rare in Arabic. The only excavators to discuss a possible equivalence for the term knidion are those who worked at Ashmūnayn. They suggested that a LRA7 type found there and dating to at least the eighth century can be identified as the knidion. ${ }^{125}$ The LRA7 is generally dated to a later period than this, while it was not made in Knidos, even though the geographical association might have been lost by this time. There is another problem, however, namely that the object found at Ashmūnayn does not correlate with the known sizes of knidion jars in the texts. ${ }^{126}$

119 Mayerson, Enigmatic especially 205, 209.

120 Bell, Metrology 22; Clackson, Coptic 26-27; Bacot, Le vin 714-715. See also Wipszycka, La Fonctionnement 170-171.

121 Bell, Metrology 23. O.Sarga 87.

122 Karabacek, Bemerkungen; Grohmann, Einführung 170.

123 P.Mird 41. For these papyri see Cotton and Millar, The papyrology 215, no. 8.

124 Grohmann, Einführung 170.

125 Bailey, Excavations 129-130; Pyke 2005, 217.

126 Bavay, Les amphores 391. 
The least common Arabic jar name in the papyri seems to be a barniyya (برنية). This jar appears in A. Ch. 2924.7, which dates to the tenth century. Diem suggests that the jar contained several truffles, ${ }^{127}$ which seems a somewhat unusual content. The jar is not attested anywhere else, which makes it difficult to speculate about what it was. In colloquial Egyptian, however, barniyya means an earthenware pot or dish glazed on the inside. ${ }^{128}$ This could suggest that ethnographically it is a jar that would normally hold liquids or be used in cooking. More attestations of this jar are needed in the papyri, however, before we can make more in depth statements about what it might be. This demonstrates, however, the evolving nature of the evidence in Arabic papyri for jar terms. There are more jar names attested in the ethnographic studies than have been found in the papyri, suggesting that there were more Arabic jar names in the early Islamic period than what we have found so far. ${ }^{129}$

\section{Coptic Terms}

The Coptic terms that have correlates in the Arabic papyri have been discussed above, but there are also terms that only appear in the Coptic. As mentioned above, due to a discrepancy in the publication record, there are many more terms known from Coptic papyri than from the Arabic. In spite of the abundance of this evidence, the treatment of Coptic jar terms has been limited to discussing the degree to which they constitute Greek loan words (such as discussed by Förster and Kruit and Worp) or 'genuinely' Coptic terms (such as discussed in Alcock, which is essentially a list from Crum's Coptic dictionary with a few additions ${ }^{130}$ ). A more complete discussion of all the Coptic terms is a desideratum and it is hoped that this article will stimulate further discussion on this topic that will examine all occurrences of the different jar names in detail and publish more texts concerning jars. Such a study may reveal whether or not certain jar names predominate in certain regions, as has been suggested for some measures which seem to predominate in the Edfu, Theban, and Oxyrhynchite areas. ${ }^{131}$ Here, the jar names under discussion will be divided into two

\footnotetext{
127 P.Vind.Arab. I 4.7. Cf. Diem's discussion of the term in the commentary to this text (p. 26).

128 Hinds and Badawi, A dictionary 70.

129 See, for example, Wassef, Pratiques 400-402.

130 Alcock, Coptic terms 1.

131 Bacot, Quelques 35, 37-38; Bacot, Le vin 716. Bacot suggests that the local measures at Edfu

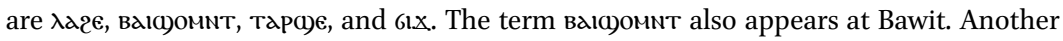


categories: those that are attested commonly (both Greek loan words and those that are Coptic) and those which are more rarely attested. Attestations from texts that date generally to the sixth/seventh century will also be included in the discussion here because they may in fact date to after the Islamic conquest.

Several Greek loanwords that are attested in Coptic and Arabic texts, such as knidion, have already been discussed, and we will now turn to those other Greek words for jars that are attested as loanwords only in Coptic and that are very common in the papyri and the ostraca. The term дгг, дггеiN, or from the Greek $\alpha \gamma \gamma \varepsilon \hat{\imath} 0 v$, and means jar. ${ }^{132}$ In Coptic texts from western Thebes the jar co ntained vinegar or oil (early 8th century), ${ }^{133}$ while Greek texts mention it containing wine (from 6th/7th-century Hermopolis/Ashmūnayn, ${ }^{134}$ late 7th-century Edfu ${ }^{135}$ and 8th- century Bawit). ${ }^{136}$ The contents are therefore similar to those mentioned in pre-Islamic documents from early seventh-century Apollonopolis Heptakomias, namely wine. ${ }^{137}$ All these texts have thus a middle or upper Egyptian provenance and refer to measures holding liquids.

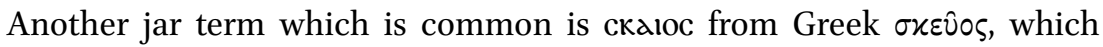
occurs frequently in Coptic texts. ${ }^{138}$ The ka৯oүc from $x \alpha \dot{\delta} 0 \varsigma$ in some cases

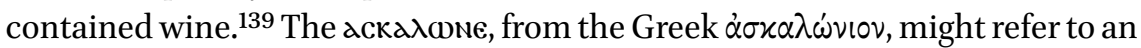
actual jar or a measure in this period. Most scholars, such as Bell, Hasitzska, and

local term from Edfu is anTdece, భenTdece, which occurs as a wine measure, and as a measure for vinegar and herbs in the wider Theban area outside of settlements such as Djeme. It can also be found at Hnes, Ashmūnayn, and Wadi Sarga. It also appears in Greek texts as $\psi \nu v \theta$ ( ) from Edfu with salt, boiled wine concentrate, must, and wine (PApoll. 93.A. 11, 12, 17 and 93.B.2.3.11, 23). See Crum, A Coptic 573b; Bacot, Du nouveau 153; Worp, Notes 571. Another local term is גакооте, which especially occurs in Middle Egypt (Bell, Metrology 23). The measure $\lambda 22 \mathrm{H}$ appears in Greek and Coptic, but while the Coptic term appears at a variety of sites such as Edfu and Bawit, in Greek papyri it is almost entirely limited to the Oxyrhynchite nome (Worp, Notes 565; Bacot, Ostraca 10, 65).

132 Förster, Wörterbuch 6-7.

133 Förster, Wörterbuch 6-7. For anren: See O.Frangé 118.7, 120.23, 343.13-14 (mentions an amphora of vinegar), aгrı: see O.Frangé 82.7 : jar(s) of oil.

134 SB 18.13585-6, 13589; P.Lond. III 1036.

135 P.Apoll. 97.

136 O.BawitIFAO 33.2. 36. 2, and possibly 38.4 (the contents are not clear in the last text).

137 P.Grenf. 1, 63, P.Drexel, and Par.suppl.gr. 1291.1. For more on P.Gren. 1, 62, its dating, and the provenance of Apollonopolis Heptakomias (Kom Isfaht) rather than Edfu, see Benaissa, Two bishops 179-180. For P.Drexel and Par. suppl. gr. 1291.1, see Bainassa, Two Bishops 184-187, 187-191. The monastery of Bawit is located in the vicinity of this city.

138 Bell, Metrology 25; P.Mon.Epiph. 3; Förster, Wörterbuch 735-737.

139 Förster, Wörterbuch $357^{-} 35^{8}$. 
Förster, believe that it is a measure but Kruit and Worp treat it as a jar. In Coptic, the term is primarily attested at Ashmūnayn, but also appears commonly at Wadi Sarga. It appears in the Coptic texts very frequently as either a measure or container for cheese ${ }^{140}$ although wine is also attested. ${ }^{141}$ Mayerson suggested

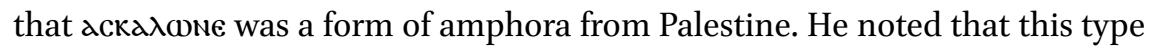
of jar contained wine, sweetmeats, fish sauce and cheese in the papyri which he felt would fit with an amphora in general. He did not discuss either the jars

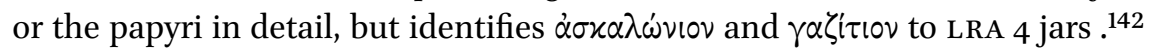
Once again, the jar name seems to have lost its meaning as a container and to have become a measure.

There are several other words that appear in Coptic whose actual origin is disputed. The word koeıc, which Crum, following Krall in $C P R$ II, suggests is also borrowed from Greek xóıs, has been thought by Worp to be a word which comes from Coptic as it is only found once in Greek. Again, however, this jar type seems to refer to quite varied types and while it normally contains wine and vinegar, it can also contain solids. At Ashmūnayn a koєıc maker is attested in the seventh century promising to deliver new koeı jars. ${ }^{143}$ It is attested in the Theban region, Bawit ${ }^{144}$ and at Edfu. ${ }^{145}$ Bacot suggests that коєıc, коловоN, and חYPP $[\mathrm{oc}]$ are jars attested at Edfu that contain wine although confusingly she also calls them measures. ${ }^{146}$ This might be the same as nopo, which is

140 O.Sarga 196, 198, 203 from Wadi Sarga; P.Lond.Copt. I 1044, 1085, 1126 from Ashmūnayn; CPR XII 30.26.

141 O.Sarga 237 and 275. Bell, Metrology 20; Hasitzska, CPR XII 40; Mayerson, The Gaza Kruit and Worp, Geographical 100 (their list provides only some of the Coptic examples); Förster, Wörterbuch 114.

142 Mayerson, The Gaza 79-80; Zemer 1977, Peacock and Williams, Amphorae 197-199; Kruit and Worp, Metrological 97; Kruit and Worp, Geographical 100-101; Gorzalczany, A baptismal 116-117. There are various varieties of southern Palestinian amphorae (Majcherek, Gazan amphorae; Fabian and Goren, A new type; Ward, From provincia arabia 199-209).

$143 \quad C P R$ II $223=C P R$ IV 35.

144 See Krall commentary on CPR II 223; Crum, A Coptic 120a; Worp, Notes 568. The exact size of this jar is unknown but it is probably smaller than a knidion jar (Kruit and Worp, A seventh-century 49).

145 O.EdfouIFAO 29; 70.

146 Bacot, Quelques 35; Bacot, Le vin 716; Bacot, Ostraca 10, 56. Kruit and Worp, A seventhcentury 49 treat коєıс as a jar. For коловом, see Kuentz, Remarques 199, who argues that it is a wine measure. Bell, Metrology 22 merely states that it has an obscure meaning but includes it in his metrology discussion, suggesting he believes it is a measure as well. Crum, A Coptic 28 also discusses it as a measure although he refers in his dictionary to it as a vessel. Kruit and Worp, A seventh-century 49 also believe this is a vessel. 
attested in 0. CrumST 117 and is defined by Crum as a jar holding oil. ${ }^{147}$ חYPP [oc] comes from the Greek word $\pi$ uppóv, red, and is equivalent to Coptic Tapo)e, which in turn is derived from the ancient Egyptian $s d d \check{r}$, red vase. The term appears not only at Edfu, but also at Jeme/Medinet Habu and the Monastery of Phoebammon. ${ }^{148}$ Kruit and Worp note that Edfu pottery includes both brown and brown with red slip ware. ${ }^{149}$ Because red is one of the most common colors in pottery this does not particularly assist in finding any archaeological correlates for this type at Edfu.

In addition to these more common loan words from Greek, there are some

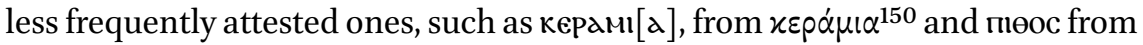
$\pi\left(\theta_{0} \varsigma^{151}\right.$ Additionally, there are two words for jars that may in fact not come

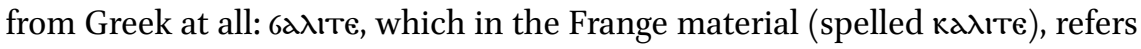
to a vessel filled with oil or simply as a vessel. ${ }^{152}$ It also appears in the Wadi Sarga texts as a vessel also filled with oil. ${ }^{153}$ Another term possibly referring to a storage vessel is opron, which holds many different types of foodstuffs. ${ }^{154}$ The word котом, which may come from the Greek word $x \dot{\omega} \theta \omega \nu$ has been attested at Edfu, and elsewhere where it contains honey, wine, and pickled food. ${ }^{155}$

147 Crum, A Coptic Dictionary 268a.

148 Kruit and Worp, A seventh-century 51. As noted by Heurtel, this word does not appear in the Coptic dictionary. Two attestations of this word which suggest that it is a measure or container (Heurtel, Reçus 151). See also Bacot, Quelques 35; Bacot, Le vin 716; Bacot, Ostraca 11, 66.

149 Kruit and Worp, A seventh-century 51.

150 Förster, Wörterbuch 405.

151 Förster, Wörterbuch 643 .

$15^{2}$ Oil: no. 88.12. Vessel: nos. 328.10 and 329.6.

153 In the dictionary Crum suggests that it is the form of $x \dot{0} \lambda \lambda \alpha \theta 0 v$ in Coptic, but he acknowledges in his commentary on O.Sarga 91 no. 4 that it does not look very similar. Bell, however, accepts the idea that the two are the same, but Förster has a question mark (Bell, Metrology 22; Crum, A Coptic 813a; Förster, Wörterbuch 428-429). Occurrences of the Greek measure $x \dot{\lambda} \lambda \alpha \theta_{0}$ in Coptic are very frequent.

154 Bell, Metrology 25. Bell argues it was a dry measure, for cheese as well as wine and pickles. He suggests that it comes from the Greek öpravov. See, however, Förster, Wörterbuch 586 , no. 7. The latter argues that this equivalence with the Greek is questionable. It is not always a vessel, however. See Crum's commentary on P.Mon.Epiph. 312, no. 1. There he states that it is a mill, wine press, or instrument.

155 Edfu: P.Mon.Epiph. $53^{2.15}$ and 543.7 (in a list). Crum commentary on P.Mon.Epiph. 543; Boud'hours and Heurtel, Les ostraca 71-72. 
There are also Coptic names for jars such as (yoc)or, which is found at Wadi Sarga and the Theban region referring to a large jar containing wine. ${ }^{156}$ It may be related to the word (a)da), which Crum defines as a vessel or measure for wine. In three cases, the jar holds the wine of Tiloj. In one case, the papyrus probably comes from the Fayyūm as it was given to the British Museum by Graf, ${ }^{157}$ while the other text, an ostracon cited by Crum, is a Theban account and another is a list of wine jars from Wadi Sarga. ${ }^{158}$ This suggests that the wines of Tilodj (Nilopolis/Dallās) were well known outside of their production center, namely the Fayyūm. ${ }^{159}$

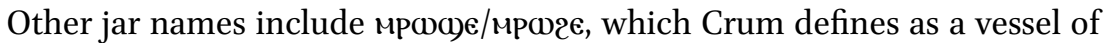
clay, ${ }^{160}$ oeınє, which is both a measure and a vessel, ${ }^{161} \lambda$ ok or $\lambda$ ak, which is a small pot (about $1 / 2$ liter in size) that contains pure honey or oil in the Frange correspondence and is referred to as a jar at Jeme without any contents listed, ${ }^{162}$ 20тc, ${ }^{163}$ and 20тTe which is a jar but also seems to be a measure or jar for bread. ${ }^{164}$ Another example is exळne, which in the texts of Frange is a vessel filled with oil. ${ }^{165}$ It is described elsewhere as a bronze vessel or as a vessel or

156 Crum, A Coptic 6oga; Bacot, Du nouveau 158-159. For some reason Alcock misspells it as ()ос)н (Alcock, Coptic terms 5).

157 P.Lond.Copt. I 697.

158 o.Sarga 135 .

159 Crum commentary on P.Lond.Copt. 697 (where he is not certain what the word means); commentary by Crum on O.Sarga 135 (where he translates the text as wine jars of (?) for Tiloj); Crum, The monestary 162, no. 5; Crum, A Coptic 6o4b-605a. For the city of Tilodj, see Timm, Das christlich-koptische 498-502.

16o Crum, A Coptic 184a; Crum commentary on P.Mon.Epiph. 549. See also Schäfer, Ein Trichter 152. Crum thinks it may have been a strainer in this context. This is followed by Wilfong, Women's 216, who notes the original editors of the O.Medin.HabuCopt. 5 translated it as vessel.

161 Crum, A Coptic 256a.

162 O.Medin.HabuCopt.5; O.Frangé 100.9 (where it refers to a jar of pure honey), 236.3 (jar of oil), 237.11, 633.10 (jar of honey), 770.18. Crum, A Coptic 138a-b, defines it as a bowl or cup or a measure for oil.

163 Crum, A Coptic 727a. This is a jar or a pot. It is attested in O.Sarga 66 as containing cheese, 186 as holding vinegar and pickles, and 344 as containing wine. See commentary of Crum on the Wadi Sarga texts on p. 148, no. 2.

164 O.Frangé 93.7, 11, 24 (Frange asks for a 20Te of bread), 328.9 and 329.4 (where it seems to be a jar). Crum, A Coptic 722a, states that it is a vase name. This is not to be confused with $2 \mathrm{H} \lambda \mathrm{e}$, which is also a measure or container for bread (Crum, A Coptic 667a; Wilfong, Women's 217, who suggests that the iron $2 a \lambda \epsilon$ and wooden $2 a \lambda \epsilon$ mentioned in O.Medin.HabuCopt. 85 are not furniture but rather bread containers or measures).

165 Nos. 87.7-8, 327.11. 
tank of metal or wood. ${ }^{166}$ It is apparently an object used in the kitchen, as it appears in a list of kitchen objects from the Theban area. ${ }^{167}$ It also may be related to a word кNN€ or kнNe, which is found in a list of vessels. ${ }^{168}$

There is evidently borrowing from Coptic into Greek as well. One word is

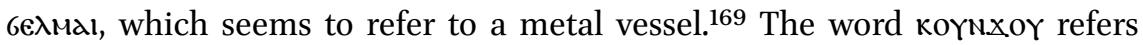

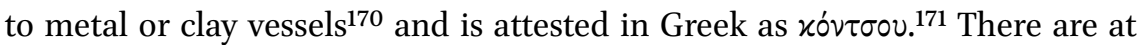

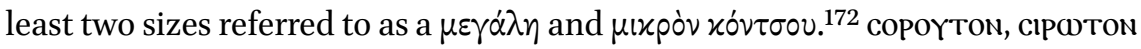
is another common word in Coptic which usually refers to a vessel holding wine or vinegar, except in two cases when the contents may be explained as "filtered" wine. ${ }^{173}$ Husselman suggested that it was a jar with a strainer on the top ${ }^{174}$ but this would argue against it being a storage jar, as transporting anything in it would be difficult. Worp has tried to connect this word to the Greek $\sigma i \rho \omega \dot{\tau} \tau(\eta \sigma) / \sigma i \rho \omega \tau o ́ v / v$. In his discussion of the term he begins by stating that it also looks similar to the Coptic word cıp, but the relationship between cıp and cІрФт remains unclear. ${ }^{175} \mathrm{clp}$ has been connected to the Arabic zir which is a common term for jar, basing his findings on a literary text. ${ }^{176}$ This has been described as a Coptic loan word in Arabic, ${ }^{177}$ although the Coptic use is limited to one attestation. ${ }^{178}$ In Greek, the term was used exclusively for containers for wine and vinegar in texts from the sixth to the eighth centuries. ${ }^{179}$ It also

\footnotetext{
166 O.Medin.HabuCopt. 5 .

167 SBKopt. II. 1048.6.

168 P.Mon.Epiph. 543; Crum, A Coptic 112a; O.Frangé, p. 72.

169 Crum, A Coptic 811a. See also Worp, Notes 570, who discusses this term in a Greek text of the sixth century.

170 Crum, A Coptic 113a; Alcock, Coptic terms 2. See also Stefanski and Licthheim, commentary on O.Medin.HabuCopt 5 no. 7. At Edfu: O.EdfouIFAO 127 is list of objects paid as wages including two jars: коүмхо (here коүхоY). The word also appears elsewhere in the Theban area (O.Frangé 631.8).

$171 S B 11160$ of unknown provenance and date (Torallas Tovar, Egyptian 169).

172 Worp, Notes $568-569$.

173 Crum, A Coptic 148, no. 3. See commentary on O.Sarga 186.7.

174 Husselman, Coptic 68.

175 Worp, Notes 569-570.

176 Crum, A Coptic 353b; Worp, Notes 569, no. 28.

177 Bishai, Coptic 47.

178 Crum, A Coptic 353b.

179 Sixth century: P.Prag. 1.92.1, SB $11960.6=$ O.Petr. 452. Seventh century: P.Apoll. 93.A.5. Early seventh century from Arsinoites: $B G U$ II 377.2. Seventh/eighth century: P.Bad. IV. 97.10.15.
} 
appears in two Coptic-Greek texts from eighth-century Bawit referring to containers for vinegar. 180

In addition to these fairly common types, there are also a number of words that are found less commonly in Coptic. What follows are some of them. Gane has been suggested to be a small vessel. ${ }^{181}$ Ga or $\mathrm{kal}^{182}{ }^{1810 \pi \epsilon,}{ }^{183}$ and $\kappa \lambda \epsilon$ refer to a vessel for honey or oil. ${ }^{184} \mathrm{ca} \varphi$ is defined as a measure or a vessel. ${ }^{185}$ c)oyo has been identified as a vessel possibly holding corn. ${ }^{186}$ 2алдг्мм may be a vessel. ${ }^{187}$ $x_{1}$ seems to be a metal vessel or utensil. ${ }^{188} \operatorname{mocn}(\epsilon)$ might be a vessel or dry

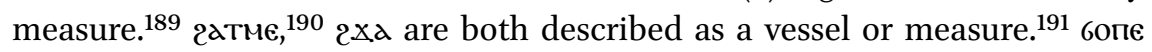
seems to be a small vessel. ${ }^{192}$ кап or бап наs been defined as a receptacle or measure for corn and honey. 193

In other cases, the meaning of the jars is not entirely clear. The word камте or Bнсc, for example, was defined by Crum as a pail or bucket in the dictionary but he has defined it as a vessel holding oil, dates, or grapes elsewhere. ${ }^{194}$ Other containers are attested in the papyri such as a water bottle (валкоү), ${ }^{195}$ bottle or tube (помкч), ${ }^{196}$ and ampoule (ампоүлє). This latter term appears twice in the correspondence of Frange who in one case asks that he be sent a large ampoule

$180 \quad$ P.Brux.Bawit 9, 13.

181 Crum, A Coptic $825 \mathrm{~b}$. This term is found primarily in literary texts, but it also appears in P.Ryl.Copt. 397. In note 10 to this text Crum suggests that it is perhaps the Coptic equivalent of the Greek word $\alpha \gamma \alpha \dot{\alpha} \pi \eta$ but he seems to have abandoned this idea by the time he wrote the dictionary.

182 Crum, A Coptic 802a. In $B K U 121$ it holds boiling water.

183 Crum, A Coptic 82a. He suggests it is either a measure or vessel for oil.

184 Crum, A Coptic 102a

185 Crum, A Coptic 378b.

186 Crum, A Coptic 6oza.

187 Crum, A Coptic 672b.

188 Crum, A Coptic 752a. This jar appears in list from Jeme/Medinet Habu where it was translated as a bronze vessel (O.Medin.HabuCopt. 27).

189 Crum, A Coptic 186b. See also O.Crum 216 (Cairo 8215). He translates it as a "small basket of olives" here. The dictionary entry does not explain why he changed his mind.

190 Crum, A Coptic 724a.

191 Crum, A Coptic 742b-743a.

192 Crum, A Coptic 825b.

193 Crum, A Coptic 113b; Crum commentary P.Mon.Epiph. 536, no. 2.

194 Crum, A Coptic 11ob; Crum commentary P.Mon.Epiph. $551 \mathrm{n}$.

195 Crum, A Coptic 38a.

196 Crum, A Coptic 266a. 
of fish sauce. ${ }^{197}$ There are also words for which the meaning remains unknown such as внв, which appears in lists of vessels ${ }^{198}$ and кNNe. ${ }^{199}$

The different products packed in these jars include wine, vinegar, honey, salted fish, garum, pickles, meat, salted preserves, herbs, olives, and cheese. ${ }^{200}$ The types of objects, and the foodstuffs they contain, that appear in the Coptic texts are similar to those attested in the Arabic papyri, but they are encountered more frequently and in more variety in the Coptic texts. It is not always clear from the papyrological evidence what type of material the vessels are made of. Sometimes the material is stated, namely pottery or metal, ${ }^{201}$ but in other cases, this is not clear at all. In the case of the word $\sigma_{2 \lambda \lambda 2} \mathrm{~T}$, for example, which Crum defines as a pot, ${ }^{202}$ the type of material is not specified. In the Frange letters published by Boud'hors and Heurtel, the word appears three times but only in one instance is it clear that a blacksmith is involved, leading the editors to suggest that it is a pot or cooking pot made from copper rather than a ceramic jar. ${ }^{203}$

As has been observed above, there have been few attempts to find archaeological correlates for the Coptic jar names. There is a large variety of different vessels attested in the texts and an equally large variety of objects attested in the archaeological record. The large numbers of terms in Coptic and a certain amount of uncertainty makes it necessary to examine these terms in considerable detail to try to determine whether certain objects are jars or measures, how they might be used and in what context. Moreover, many of the sites where a large number of texts have been recovered and studied have not been published archaeologically. ${ }^{204}$

The site of TT29, however, provides considerable information about pottery production and consumption, both from an archaeological and textual point of view. At the site, archaeologists have discovered the voluminous correspon-

197 O.Frangé 53.15 (commentary Boud'hours and Heurtel, Les ostraca 71-72); O.Bale inv. Lg Ae BJF 31C (commentary Boud'hors, Pièces 105-106).

198 Crum, A Coptic 28b.

199 Crum, A Coptic 112a.

$200 \quad$ Kruit and Worp, Geographical 138; Worp 2004, $55^{8}$.

201 See, for example, O. Medin.HabuCopt. 27.1 and 7, which notes that the jar 6onxor is made of bronze. This term is not attested in Crum (Crum, A Coptic 113a, 184a; Alcock, Coptic terms 2). See also Stefanski and Licthheim, commentary on O.Medin.HabuCopt. 5 no. 7 ; Crum commentary on P.Mon.Epiph. 549 .

202 Crum, A Coptic 813b-814a.

203 O.Frangé 79.10-11 and commentary.

204 Bavay, Les amorphes 391. 
dence of the anchorite Frange, as well as large amounts of pottery from the same context. ${ }^{205}$ This combined evidence provides information about what the anchorite ate and insights about the operations of exchange and transport which were conducted in order to keep him provisioned. The pottery dates to the first part of the eighth century and is very homogeneous which has led to the suggestion that the material might have belonged to the anchorite and those who lived around him. The pottery consists of LRA7 from Ashmūnayn (a type that also occurs frequently at the Monastery of Epiphanius), pottery that has similarities to jars found at Elephantine and Tod, amphorae from Aswan and local imitations of Aswan amphorae made in middle Egypt which are found frequently in the Theban area. ${ }^{206}$ But it is difficult to know which of the jar names used in Frange's correspondence can be connected to the amphorae found archaeologically. Once the ceramics from the site have been published, it will be interesting to make a detailed analysis of both the texts and the pottery.

\section{Conclusion}

A wide variety of different types of jars have been found at sites all over Egypt. Similarly, the Coptic, Greek and Arabic papyrological material contains numerous references to jars and containers. The difficulty is trying to understand how the archaeology and the papyri can be connected. The Arabic evidence remains small and there are not enough names known from the papyri to match the variety of archaeological attested material. Moreover, like the Greek and Coptic textual material the Arabic papyri lack exactitude and details in the descriptions needed for exact matching. This leads to a certain amount of confusion. It also means that it is difficult to make exact correlates. The appearance of new papyrological terms, especially from newly published Arabic material, has made it clear that there are doubtlessly many more attestations of jars in the papyri that are waiting to be published. The ethnographic evidence shows not only that there is a wide variety of different names for jars, but also how the names of jars have evolved through time and changed their meaning. The fact that there are different sizes of jars and that different types of materials are used for jars that carry the same name, suggests that the same term is applied to different types of vessels, something which also exists concerning the ethnographic terms.

205 O.Frangé 21.

206 Bavay, Les amphores 390-391, 394-397. 
The Coptic documentary papyri provide a far more complete picture of the large number of jar names that exists although more work is needed before a clear picture emerges. The information available so far does indicate that many jars seem to have had their own specific names. Finally, the papyrological evidence provides a good corrective to the archaeological record. There is often the tendency in archaeology to assume that storage jars found on sites would have always contained wine. The large variety of commodities attested in the papyri shows that this need not be the case and that the picture is far more complex. Indeed, the attempts to correlate papyri and archaeology in general show that although we are sometimes limited by what has been published, this unique material is still the best way to help us to understand consumption patterns better in early Islamic Egypt.

\section{Bibliography}

Alcock, A., Coptic terms for containers and measures, in Enchoria 23 (1996), 1-7.

Alcock, J.P., Food in Roman Britain, Stroud 2001.

Alfen, P. van., New light on the 7th-c. Yassi Ada shipwreck: Capacities and standard sizes of LRA1 amphorae, in Journal of Roman archaeology 9 (1996), 189-213.

Allen, J.W., Nishapur: Metalwork of the early Islamic period, New York 1982.

C Concave or convex? The sources of Jazīran and Syrian metalwork in the 13th century, in J. Raby (ed.), The art of Syria and the Jazira: 1100-1200 (Oxford studies in Islamic art 1), Oxford 1985, 127-139.

- Metalwork of the Islamic world: The Aron collection, London 1986.

Ashton, S.-A., Comparative ceramics from al-Qasr, 2001, www.learn.columbia.edu/ amheida/html/2001_field_reports/comparative_ceramics.hml. 2001.

Aston, D., Amphorae, storage jars and kegs from Elephatine: A brief survey of vessels from the eighth-seventh centuries BC to the seventh-eighth centuries AD, in Cahier de la céramique égyptienne 8 (2007), 419-445.

Bacharach, J.L., Introduction, in J.L. Bacharach (ed.), Fustat finds: Beads, coins, medical instruments, textiles, and other artifacts from the Awad collection, New York 2002, 1-11.

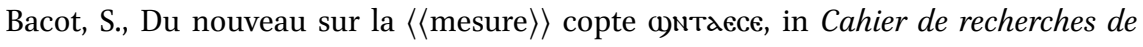
l'Institute de Papyrologie et d'Egyptologie de Lille 18 (1996), 153-160.

. Quelques textes relatifs aux mesures du vin d'Edfou au vire siècle, in A. Boud'hors, J. Gascou and D. Vaillancourt (eds.), Études coptes IX, Onzième journée d'études (Strasbourg, 12-14 juin 2003) (Cahiers de la Bibliothèque copte 14), Paris (2006), 33-44.

. Le vin à Edfu, in Cahier de la céramique égyptienne 8 (2007), 713-720. 
—. Ostracagrecs et coptes de TellEdfou. O.EdfouCopte 1-145 (Bibliothèque d'études coptes 19), Cairo 2009.

Bacot, S. and C. Heurtel, Ostraca coptes d'Elephantiné au musée du Louvre, in N. Bosson (ed.), Études coptes VII, Neuvième journée d'études (Montpellier, 3-4 juin 1999) (Cahiers de la Bibliothèque copte 12), Paris (2000), 17-46.

Baer, E., Metalwork in medieval Islamic art, Albany 1983.

Bailey, D.M., Gaza jars not baggy amphorae, in Zeitschrift für Papyrologie und Epigraphik 94 (1992), 295-296.

- Marsa Matruh: The resurfacing of ancient Paraetonium and its ongoing reburial. A preliminary note on Greek, Hellenistic and Roman pottery, in D.M. Bailey (ed.), Archaeological research in Roman Egypt. Proceedings of the seventeenth classical colloquim of the department of Greek and Roman antiquities, British Museum, held on 1-4 December, 1993 (Journal of Roman archaeology supplementary series 19), Ann Arbor 1996, 61-81.

- Excavations at el-Ashmünayn v: Pottery, lamps and glass of the late Roman and early Arab periods, London 1998.

Ballet, P., Un atelier d' amphore Late Roman amphora 5/6 à Kôm Abu Billou (Egypte), in Chronique d'Égypte 137-138 (1994), 353-365.

. De l'Égypte byzantine à l'islam. Approches céramologiques, in Archéologie Islamique 10 (2000), 29-53.

- La céramique contextes et classification, in P. Ballet, N. Bosson, and M. RassartDebergh, Kellia II. L'ermitage copte QR 195 2. céramique, inscriptions, décors (Fouilles de l'IFAO 49), Cairo (2003), 1-207.

—. Un atelier d' amphores LRA $5 / 6$ à pate alluviale dans le Delta occidental Kôm Abu Billou/Térénouthis, in Cahier de la céramique égyptienne 8 (2009), 157-16o.

- Les amphores de Kysis/Douch (1985-1990) Oasis de Kharga, in Cahier de la céramique égyptienne 8 (2009), 481-487.

—_. 'Uyûn Mûsâ et sa production d' amphores byzantines ou proto-Islamiques, in Cahier de la céramique égyptienne 8 (2009), 621-626.

Ballet, P. and D. Dixneuf, Ateliers d'amphores de la chôra égyptienne aux époques romaine et byzantine, in J. Eiring and J. Lund (eds.), Transport amphorae and trade in the eastern Mediterranean. Acts of the international colloquium at the Danish Institute at Athens, September 26-29, 2002 (Monographs of the Danish Institute at Athens volume 5), Arhus 2004, 67-72.

Ballet, P., F. Mahmoud, M. Vichy and M. Picon, Artisanat de la céramique dans l'Égypte romaine tardive et byzantine: prospections d' ateliers de potiers de Minia à Assouan, in P.Ballet (ed.), Cahiers de la céramique égyptienne vol. 2, 129-144.

Ballet, P. and M. Picon, Recherches préliminaires sur les origines de la céramique des Kellia (Egypte):Importations et productions égyptiennes, in Cahiers de la Céramique Égyptienne 1 (1987), 17-48. 
Balog, P., Umayyad, 'Abbāsid, Ṭūlūnid glass weights and vessel stamps (Numismatic studies no. 13), New York 1976.

Bates, M.L., The function of Fāțimid and Ayyūbid glass weights, in Journal of the economic and social history of the Orient 24 (1981), 63-92.

Bavay, L., Les amphores d'un anchorète copte de la montagne thébaine, in Cahier de la céramique égyptienne 8 (2007), 389-399.

Bell, H.I., Metrology, in W.E. Crum and H.I. Bell (eds.), Wadi Sarga, Coptic and Greektexts from the excavations undertaken by the Byzantine research account (Coptica Consilio et Impensis Instituti Rask-Oerstediani III), Hauniae 1922, 28-29.

Benaissa, A., Two bishops named Senuthes: Prospography and new texts, in Zeitschrift für Papyrologie und Epigraphik 166 (2008), 179-194.

Bénazeth, D., La vaisselle de bronze conservée au Musée Copte du Caire. Étude préliminaire à un catalogue, in Antiquité Tardive 13 (2005), 99-104.

Bénazeth, D. and M. van Strydonck, Carbone 14 et archéologie copte: la sépulture de Thaïas à Antinoé, in A. Boud'hors, J. Gascou and D. Vaillancourt (eds.), Études coptes IX, Onzième journée d'études (Strasbourg, 12-14juin 2003) (Cahiers de la Bibliothèque copte 14), Paris 2006,45-65.

Bilabel, F., Neue literarische Funde in der Heidelberger Papyrussammlung, in Actes $d u$ VE congrès international de papyrologie Oxford, Brussels 1938, 72-84.

Bilabel, F. and A. Grohmann, Griechische, koptische und arabische Texte zur Religion und religiösen Literatur in Ägyptens Spätzeit, Heidelberg 1934.

Bishai, W.B., Coptic lexical influence on Egyptian Arabic, in Journal of Near Eastern studies 23 (1964), 39-47.

Blackman, W.S., The fellahin of Upper Egypt: Their religious social and industrial life to-day with special references to survivals from ancient times, London 1927.

Blakely, J.A., Ceramics and commerce: Amphorae from Caesarea Maritima, in Bulletin of the American school of Oriental research 271 (1988), 31-50.

Bonnet, F., Le matériel archéologique récolté en 1977, 1982 et 1983 aux Qouçoûr er Roubâ̂îyât, in Tome II: Explorations aux Qoucour Er-Roub'iyt. Rapport des campagnes 1982 et 1983 (Kellia), P. Bridel and R. Kasser (eds.), Louvain 1994, 349-406.

Brissaud, P., Les ateliers de potiers de la région de Louqsor, Cairo 1982.

Boud'hors, A., Ostraca grecs et coptes des fouilles de Jean Maspero à Baouit. O.BawitIFAO 1-67 et O. Nancy (Bibliothèque d'études coptes 17), Cairo 2004.

—. Pièces supplémentaires du dossier de Frangé, in Journal of Coptic studies (2011), 99-122.

Boud'hors, A. and C. Heurtel, Les ostraca coptes de la TT 29. Autour du moine Frangé, (Études d' archéologie thébaine 3), Brussels 2010. [= O.Frangé]

Calament, F., La révélation d'Antinoé par Albert Gayet: Histoire, archéologie, muséographie. Volume 2 (Bibliothèque d'études coptes 18/2), Cairo 2005.

Černý, J., Coptic etymological dictionary, Cambridge 1971. 
Chouliara-Raïos, H., L'abeille et le miel en Égypte d'apres les papyrus Grecs, Jannina 1989. Clackson, S.J., Coptic and Greek texts relating to the Hermopolite monastery of Apa Apollo, Oxford 2000.

Cohen, R., Kissufim, in Israel exploration journal 27 (1977), 255-256.

Cotton H.M. and F.G.B. Millar, The papyrology of the Roman Near East: A survey, in Journal of Roman studies 85 (1995), 214-235.

Crum, W.E., A Coptic dictionary, Oxford 1939.

Crum, W.E., The monastery of Epiphanius at Thebes. Part I. The Metropolitan Museum of Art Egyptian expedition, New York 1926.

Curtis, R.I., Garum and Salsamenta: Production and Commerce in Materia Medica (Studies in Ancient Medicine Volume 3), Leiden 1991.

David-Weill, J., Papyrus arabes du Louvre II, in Journal of the economic and social history of the Orient 14 (1971), 1-24.

Day, F., An Umayyad pharmacist's measuring cup, in Bulletin of the Metropolitan Museum of Art 11 (1953), 259.

Decker, M., Food for an empire: Wine and oil production in north Syria, in S. Kingsley and M. Decker (eds.), Economy and exchange in the east Mediterranean during late antiquity, Oxford 2001, 69-86.

Diethart, J.M., Neue papyri zur Realienkunde, in Zeitschrift für Papyrologie und Epigraphik 64 (1986), 75-81.

Dixneuf, D., Amphores égyptiennes: Production, typologie, contenu et diffusion (IIIe siècle avant J.-C.-XIe siècle après J.-C.) (Études Alexandrines 22), Alexandria 2011.

Egloff, M., Kellia. La Poterie Copte, Geneve 1977.

Eldada, K., Glass weights and vessel stamps, in J.L. Bacharach (ed.), Fustat finds: Beads, coins, medical instruments, textiles, and other artifacts from the Awad collection, New York 2002, 112-166.

Empereur, J.-Y. and Picon, M., Les régions de production d'amphores impériales en Méditerranée orientale, in Amphores romaines et histoire économique: dix ans de recherche (Collection de l'École française de Rome 114), Rome 1989, 236-243.

Engemann, J., À Propos des Amphores d'Abou Mina, in Cahier de la céramique égyptienne 3 (1992), 153-16o.

Fabian, P. and Y. Goren, A new type of late Roman storage jar from the Negev, in J.H. Humphrey (ed.), The Roman and Byzantine Near East volume 3 (Journal of Roman archaeology supplementary series number 49), Portsmouth, RI 2002, 145153.

Faiers, J., A corpus of late Roman pottery from Kom el-Nana, in J. Faiers (ed.), Late Roman pottery at Amarna and related studies, London 2005, 57-180.

Fehérvári, G., Islamic metalwork of the eighth to the fifteenth century in the Keir collection, London 1976.

Formenti, F. and J.M. Duthel, The analysis of wine and other organics inside amphoras 
of the Roman period, in P.E. McGovern, S.J. Fleming, and S.H. Katz (eds.), The origins and ancient history of wine, Amsterdam 1996, 79-88.

Förster, H., Wörterbuch der griechischen Wörter in den koptischen dokumentarischen Texten, Berlin and New York 2002.

Foy, D., Secteur nord de Tebtynis (Fayyoum). Le verre byzantine et islamique, AI 35 (2000), 465-489.

Foy, D. and M.-D. Nenna (eds.), Tout feu, tout sable: Mille ans de verre antique dans le Midi de la France, Aix-en-Provence 2001.

Gascoigne, A., Amphorae from old Cairo: A preliminary note, in Cahier de la céramique égyptienne 8 (2007), 161-173.

Gayet, A., Antinoë et les sépultures de Thaïs et Sérapion, Paris 1902.

Gladiss, A. von and Kröger, J., Islamische Kunst. Loseblattkatalog Unpublizierter Werke aus Deutchsen Museen. Berlin. Staatliche Museen Preussischer Kulturbesitz. Musem für Islamische Kunst. Band 2. Metall, Stein, Stuck, Holzm Elfenbein Stoffe, Mainz 1985 .

Gempeler, R.D., Elephantine x: Die Keramik römischer bis früharabischer Zeit (Archeologische Veröffentlichungen 43), Mainz 1992.

Ghaly, H., Pottery workshops of Saint-Jeremia (Saqqara), in Cahier de la céramique égyptienne 3 (1992), 161-172.

Godlewski, W., T. Derda and T. Górecki, Deir el Naqlun (Nekloni), 1988-1989, Second Preliminary Report, in Nubica III/I (1994), 201-263.

Golvin, L., J. Thiriot and M. Zakariya, Les potiers actuels de Fusțāt, Cairo 1982.

Górecki, T., Deir el-Naqlun 1992: The pottery, in Polish Archaeology in the Mediterranean 4 (1993), 53-64.

Gorzalczany, A., A baptismal font at Nir Gallim, in Atiqot 43 (2002), 115-118.

Grohmann, A., From the world of Arabic papyri, Cairo $195^{2}$.

Einführung und Chrestomathie zur Arabischen Papyruskunde, Prague 1954.

Greene, K., The archaeology of the Roman economy, Berkeley and Los Angeles 1986.

Guidotti, M.-C. and L. Pesi, La ceramica da Antinoe nell'Istituto papyroogico $\langle\langle G$. Vitelli $\rangle\rangle$ (Studi e Testi di Papirologia N.s. 6), Florence 2004.

Hall, H.R., Coptic and Greek texts of the Christian period from Ostraka, Stelae, etc. in the British Museum, London 1905.

Hamarneh, S.K. and H.A. Awad, Glass vessel stamp data for materia medica, in J.L. Bacharach (ed.), Fustat finds: Beads, coins, medical instruments, textiles, and other artifacts from the Awad collection, New York 2002, 167-175.

Hassel, F.J., Glasamphore im Deckelkorbe, in Jahrbuch des Römisch-Germanischen Zentralmuseums Mainz 33 (1986), 908-909.

Hayes, J.W., The pottery, in S. Sidebotham and W. Wendrich (eds.), Berenike '95: Report of the excavations at Berenike (Egyptian Red Sea coast) and the survey of the eastern Desert, Leiden 1996, 147-178. 
Heidemann, S., Katalog der Fundmünzen aus ar-Raqqa/ar-Rāfiqa, in S. Heidemann and A. Becker (eds.), Raqqa II. Die islamische Stadt, Mainz 2003, 169-196.

Heidorn, L., Pottery from the 1993 survey, in C. Meyer, L. Heidorn, W.E. Kaegi et. al., eds. Birr Umm Fawakhir survey project 1993: A Byzantine gold mining town in Egypt (OIC No. 28), Chicago 2000, 27-42.

Henein, N.H., Poterie et potiers d'al-Qasr. Oasis de Dakhla, Cairo 1997.

Henne, H., Rapport sur les fouilles de Tell Edfou (1921-1922), Cairo 1924.

Heurtel, C., Reçus coptes d'Edfou, in M. Rassart-Deberg (ed.), Études coptes V, Septième journée d'études (Neuchâtel, 18-20 mai 1995) (Cahiers de la Bibliothèque copte 10), Paris 1998, 137-153.

. Écrits et écritures de Marc, in A. Boud'hors and C. Louis (eds.), Études coptes XI, Treizième journée d'études (Marseille, 7-9 juin 2007) (Cahiers de la Bibliothèque copte 17), Paris 2010, 139-150.

Hill, D.R., The book of ingenious devices (Kitāb al-Hiyal) by the Banū (sons of) Mūsā bin Šākir, Dordrecht, Boston and London 1979.

Hinds, M. and E.-S. Badawi, A dictionary of Egyptian Arabic, Beirut 1986.

Hinz, W., Islamische Masse und Gewichte: Umgerechnet ins metrische System. Leiden, 1955.

Hope, C.A., Dakhleh oasis project. Report on the study of the pottery and kilns. Third season-1980, in Journal of the society for the study of Eyptian antiquities XI (1981), $233-241$.

Husselman, E., Coptic documents from the Michigan collection, in Bulletin of the American society of papyrologists 19 (1982), 61-70.

Johnson, W.R. and D.S. Whitcomb, Pottery, in D.S. Whitcomb and J.H. Johnson (eds.), Qușayr al-Qadim 1978 preliminary report, Princeton 1979, 67-143.

Karabacek, J., Bemerkungen zu Adalbert Merx: Documents de Paleographie hébraique et Arabe, in Wiener Zeitschrift für die Kunde des Morgenlandes VIII (1894), 293294.

Kingsley, S., The economic impact of the Palestinian wine trade in late antiquity, in S. Kingsley and M. Decker (eds.), Economy and exchange in the eastern Mediterranean during late antiquity, Oxford 2001, 44-68.

Knauer, E.R., Marble jar-stands from Egypt, in Metropolitan Museum of Art journal 14 (1979), 67-101.

Kröger, J., Islamische Kunst. Loseblattkatalog unpublizierter Werke aus deutschen Museen Band I. Glas, Mainz 1984.

Kruit, N. and K.A. Worp, Metrological notes on measures and containers of liquids, in Archiv für Papyrusforschung 45 (1999), 96-127.

- Geographical jar names: Towards a multi-Disciplinary approach, in Archiv für Papyrusforschung 46 (2000), 65-146. 
A seventh-century list of jars from Edfu, in Bulletin of the American society of papyrologists 39 (2002), 47-56.

Kuentz, C., Remarques philologiques, in B. Bruyère, J. Manteuffel, K. Michałowski et al., Tell Edfou I 1937, Cairo 1937, 193-208.

Lamm, C., Mittelalterliche Gläser und Steinschnittarbeiten aus dem Nahen Orient, Berlin 1930.

Lane, E.W., Manners and customs of modern Egyptians, New York 1954, first published 1860.

Lane-Poole, S., Catalogue of Arabic glass weights in the British Museum, London 1891.

Lecuyot, G., Amphores provenant de Thèbes-Ouest de la Basse Époque à l'époque copte, in Cahier de la céramique égyptienne 8 (2007), 377-387.

Lecuyot, G. and G. Pierrat-Bonnefois, Corpus de la céramique de Tôd:Fouilles 1980-1983 et 1990, Cahier de la céramique égyptienne 7 (2004), 145-210.

Majchrek, G., Roman amphorae from Marina el-Alamein, in Mittleinungen der Deutschen Archäologischen Instituts, Abteilung Kairo 49 (1993), 215-220.

— Gazan amphorae: Typology reconsidered, in H. Meyza and J. Młynarczyk (eds.), Hellenistic and Roman pottery in the eastern Mediterranean-advances in scientific studies. Acts of the II Nieborów pottery workshop, Nieborów, 18-2o December 1993, Warsaw 1995, 163-178.

- Marea 2001: Note on the pottery, in Polish archaeology in the Mediterranean 13 (2002), 60-64.

- Alexandria's long-distance trade in late antiquity - the amphora evidence, in: J. Eiring and J. Lund (eds.), Transport amphorae and trade in the eastern Mediterranean. Acts of the international colloquium at the Danish Institute at Athens, September 26-29, 2002 (Monographs of the Danish Institute at Athens volume 5), Arhus 2004, 229-238.

Manning, S.W., S.J. Monks, D.A. Sewell, et al, Late Roman type 1a amphorae production at the late Roman site of Zygi-Petrini, Cyprus, in Report of the department of antiquities, Cyprus 2000, 233-258.

Marangou, A. and S. Marchand, Conteneurs importés et égyptiens de Tebtynis (Fayoum) de la deuxième moitié du Ive siècle av. J.-C. au XE siècle apr. J.-C. (1994-2002), in Cahier de la céramique égyptienne 8 (2007), 239-307.

Marchand. S., Les amphores égyptiennes et importées de la Basse Époque à l'époque arabe Abou Rawash (1995-2004), in Cahier de la céramique égyptienne 8 (2007), $175^{-188 .}$

—. Les conteneurs de transport et de stockage de l' oasis de Kharga de la Basse Époque (XXviı-Xxxe dynasties) à l' époque ptolémaïque, in Cahier de la céramique égyptienne 8 (2007), 489-503.

Marchand, S. and D. Dixneuf, Amphores et conteneurs égyptiens et importés du viIe 
siècle apr. J.-C. Sondages récents de Baouît (2003-2004), in Cahier de la céramique égyptienne 8 (2007), 309-343.

Marrow, S., Two Arabic private exchanges (P. Palau Rib. inv. 35 and 36), in Studia papyrologica 8 (1969), 111-114.

Mayerson, P., The Gaza 'wine' jar (Gazition) and the 'lost' Ashkelon (Askalônion), in Israel Exploration Journal 42 (1992), 76-80.

. A note on xoṽ $\alpha$ 'empties,' in Bulletin of the American society of papyrologists 34 (1997), 47-52.

- The knidion jar in Egypt: Popular, made in Egypt, and of unknown capacity, in Zeitschrift für Papyrologie und Epigraphik 131 (2000), 165-166.

- Radish oil: A phenomenon in Roman Egypt, in Bulletin of the American society of papyrologists 38 (2001), 109-118.

- Enigmatic knidion: A wine measure in late Roman/Byzantine Egypt?, in Zeitschrift für Papyrologie und Epigraphik 141 (2002), 205-209.

—. Pitch $(\pi i \sigma \sigma \alpha)$ for Egyptian winejars an imported commodity, in Zeitschrift für Papyrologie und Epigraphik 147 (2004), 201-204.

Meredith, H., Evaluating the movement of open-work glassware in late antiquity, in M. Mango (ed.), Byzantine trade, 4th-12th centuries. The archaeologiy of local, regional and international exchange. Papers of the thirty-eighth spring symposium of Byzantine studies. St.John's College. University of Oxford March 2004 (Society for the promotion of Byzantine Studies-publication 14), Farnham 2009, 191-197.

Mershen, B., Recent hand-made pottery from northern Jordan, in Berytus 33 (1985), $75^{-87}$.

Miles, G.C., Contributions to Arabic metrology I. Early Arabic glass weights and measure stamps. Acquired by the ANs 1951-1956, New York $195^{8}$.

- Egyptian glass pharmaceutical measures of the 8th century A.D., Journal of the history of medicine and allied sciences 15 (1960), 384-389.

Mond, R. and O. Meyers, The Bucheum, London 1934.

- Temples of Armant: A preliminary survey, London 1940.

Morton, A.H., A catalogue of early Islamic glass stamps in the British Museum, London 1985 .

Mossakowska-Gaubert, M., La verrerie utilisée par des anachorètes: l'ermitage no. 44 à Naqlun (Fayyoum), in M. Immerzeel and J. van der Vliet (eds.), Coptic studies on the threshold of a new millennium I. Proceedings of the seventh international congress of Coptic studies. Leiden 2000 (Orientalia Lovaniensia Analecta [OLA] 133), Leuven 2004, 1443-1469.

Mouny, S., Note préliminaire sur les amphores et première approche typologie et morphologique des conteneurs trouvés sur la fortresse de Qal'at al-Guindî (Sadr, Sinaï central), in Cahier de la céramique égyptienne 8 (2007), 627-637.

Mango, M., Beyond the amphora: Non-ceramic evidence for late antique industry 
and trade, in S. Kingsley and M. Decker (eds.), Economy and exchange in the east Mediterranean during late antiquity, Oxford 2001, 87-106.

- Tracking Byzantine silver and copper metalware, 4th-12th centuries, in M. Mango (ed.), Byzantine trade, 4th-12th centuries. The archaeologiy of local, regional and international exchange. Papers of the thirty-eighth spring symposium of Byzantine studies. St.John's College. University of Oxford March 2004 (Society for the promotion of Byzantine studies - publication 14), Farnham 2001, 221-236.

N.A., Recent important acquisitions made by public and private collections in the United States and abroad, in Journal of glass studies 22 (1978), 119-126.

Nicholson, P.T., Deir Mawas and Deir el-Gharbi: Two contrasting ceramic traditions, in W. Wendrich and G. van der Kooij (eds.), Moving matters: Ethnoarchaeology in the Near East. Proceedings of the international seminar held at Cairo 7-10 December 1998, Leiden 2002.

Opait, A., On the origin of Carthage LR amphora 1, in S. Menchelli, S. Santoro, M. Pasquinucci et al. (eds.), LRCW 3 : Late Roman coarse wares, cooking wares and amphorae in the Mediterranean: Archaeology and archaeometry. Comparison between western and eastern Mediterranean. Volume II (BAR international series 2185 (II)), Oxford 2010, 1015-1022.

Orssaud, D., De passage de la céramique byzantine a la céramique islamique: Quelques hypothèses à partir du mobilier trouvé à Déhès, in P. Canivet and J.-P. Rey-Coquais (eds.), La Syrie de byzance à l'Islam. VIIe-VIIIe siècles. Actes du Colloque international Lyon - Maison de l'Orient Méditerranéen Paris —Institut du Monde Arabe 11-15 Septembre 199o. Damascus 1992, 219-228.

Peacock, D.P.S. and D.F. Williams, Amphorae and the Roman economy: An introductory guide, London and New York 1986.

Pierrat, G., Essai de classification de la céramique de Tôd de la fin du viıe siècle au début du XıIIe siècle apr. J.-C., in Cahier de la céramique égyptienne 2 (1991), 145-204.

Pitarakis, B., Une production caractéristique de cruches en alliage cuivreux (vıe-VIIIe siècles): Typologie, techniques et diffusion, in Antiquité Tardive 13 (2005), 11-27.

Pyke, G., Late Egyptian amphorae from squares $\mathrm{U}$ and v at Kom el-Nana, in J. Faiers (ed.), Late Roman pottery at Amarna and related studies, London 2005, 213-243.

Quecke, H., Eine griechische-ägyptische Wörterliste vermutlich des 3. Jh. v. Chr., in Zeitschrift für Papyrologie und Epigraphik 116 (1997), 67-80.

Rāgib, Y., Quatre papyrus arabes d'Edfou, in Annales Islamologiques 14 (1978), 1-14.

Rogers, E.T., Unpublished glass weights and measures, in Journal of the Royal Asiatic Society 10 (1878), 98-112.

Ross, M.C., Byzantine and early medieval antiquities in the Dumbarton Oaks collection, in Volume I. Metalwork, ceramics, glass, gylptics, painting, Washington, D.C. 1962.

Rougelle, A., Excavations at Sharmah, Hadramawt: The 2001 and 2002 seasons, in Proceedings of the seminar on Arabian studies 33 (2003), 287-305. 
Rousset, M.-O. and Marchand, S., Secteur nord de Tebtynis (Fayyoum) Mission de 1999, in Annales Islamologiques 34 (2000), 387-436.

. Secteur nord de Tebtynis (Fayyoum) Mission de 2000, in Annales Islamologiques 35 (2001), 409-464.

Rousset, M.-O. and S. Marchand with D. Laisney and S. Robert, Tebtynis 1998. Travaux dans le secteur nord, in Annales Islamologiques 33 (1999), 185-262.

Sams, G.K., The weighting implements, in G.F. Bass and F.H.van Doorninck (eds.), Yassi Ada I. Volume 1. A seventh-century Byzantine shipwreck, College Station 1982, 202-230.

Sauvaire, H., On a treatise on weights and measures by Eliyá, Archbishop of Nisíbín, in Journal of the Royal Asiatic Society 9 (1877), 291-313.

. Arabic metrology II. El-Djabaraty, in Journal of the Royal Asiatic Society 10 (1878), 253-284.

- A treatise on weights and measures by Eliyá, Archbishop of Nisíbín, in Journal of the Royal Asiatic Society 12 (1880), 110-125.

-. Arab metrology V. Ez-Zahrâwy, in Journal of the Royal Asiatic Society 16 (1884), 495-524.

Schäfer, H., Ein Trichter mit koptischer Weihinschrift, in Zeitschrift für Ägyptische Sprache und Altertumskunde 39 (1901), 151-152.

Scanlon, G. and Pinder-Wilson, R., Fustat glass of the early Islamic period. Finds excavated by the American research center in Egypt 1964-1980, London 2001.

Sedov, A.V., New archaeological and epigraphical material from Qana (South Arabia), in Arabian archaeology and epigraphy 3 (1992), 110-137.

Sidebotham, S., Bernard, H. and Pyke G., Late Roman settlements in the eastern desert, in Journal of Egyptian archaeology 88 (2002), 187-226.

Simony, A., Étude céramologique des salles annexes de la tombe de Merneptah (KV.8), in Memnonia 21 (2010), 149-182.

Spiro, S., An Arabic-English dictionary of the colloquial Arabic of Egypt, Beirut 1980.

Stegemann, V., Neue Zauber- und Gebetstexte, in Le Muséon $5^{1}$ (1938), 73-87.

Stern, E.M., Roman mold-blown glass: The first through sixth centuries, Toledo 1995.

Taniguchi, Y., Ethnoarchaeological research on a modern pottery workshop in Qamishli, Syria, in Berytus XLVII (2003), 143-166.

Timm, S., Das christlich-koptische Ägypten in arabischer Zeit. Teil $2(D-F)$ (Beiheft zum Tübinger Atlas des Vorderen Orients Reihe в (Geisteswissenschaften) Nr. 41/2), Wiesbaden 1984.

Tomber, R., Pottery, in The Roman imperial quarriers: Survey and excavation at Mons Porphyrites 1994-1998. Volume One: Topography and quarries, London 2001, 242-305.

Torallas Tovar, S., Egyptian lexical interference in the Greek of Byzantine and early Islamic Egypt, in P.M. Sijpesteijn and L. Sundelin (eds.), Papyrology and history of early Islamic Egypt (Islamic history and civilization. Studies and texts vol. 55), Leiden 2004, 163-177. 
Vliet, J. van der, Varia Magica Coptica, in Aegyptus 71 (1991), 217-242.

Vogt, C., Les céramiques ommeyyades et abbasides d' Istabl Antar-Fostat: Traditions méditerranéennes et influences orientales, in G.D. d'Archimbaud (ed.), La céramique médiévale en méditerrannée. Actes du vie congrès de l'Annales Islamologiques ECM2. Aix-en-Provence (13-18 novembre 1995), Aix-en-Provence 1997, 243-26o.

Vogt, C., P. Gouin, G. Bourgeois et al, Notes on some of the Abbasid amphorae of Istabl 'Antar-Fustat (Egypt), in Bulletin of the American schools of Oriental research 326 (2002), 65-80.

Waldbaum, J., Metalwork from Sardis, the Finds through 1974, Cambridge, M.A. 1983.

Ward, R., Islamic metalwork, London 1993.

Ward, W.D., From provincia arabia to palaestina tertia: The impact of geography, economy, and religion on sedentary and nomadic communities in the later Roman province of Third Palestine, PhD thesis, University of California, Los Angeles 2008.

Wassef, C.W., Pratiques rituelles et alimentaires des Coptes, Cairo 1971.

Whitbread, I.K., Greek transport amphorae: A petrological and archaeological study (British School at Athens, Fitch Laboratory occasional papers, 4), Athens 1995.

Whitcomb, D.S., Islamic ceramics, in D.S. Whitcomb and J.H. Johnson (eds.), Qușayr al-Qadim 1980 preliminary report (American Research Centre in Egypt reports volume 7), Malibu 1982, 133-192.

Wilfong, T., Women's things and men's things: Notes on gender and property at Jeme, in Bulletin of the American society of papyrologists 40 (2003), 213-221.

Wilson, P. and D. Grigoropoulos, The west Delta regional survey, Beheira and Kafr elSheikh provinces (EES excavation memoir 86), London 2009.

Wipszycka, W., La Fonctionnement interne des monastères et des laures en Égypte du point de vue économique, in Journal for juristic papyrology 31 (2001), 169-186.

Worp, K., Notes on Coptic containers of liquids in Greek papyri, in M. Immerzeel and J. van der Vliet (eds.), Coptic studies in the threshold of a new millennium I. Proceedings of the seventh international congress of Coptic studies Leiden, 27 August-2 September 2000 (OLA 133), Leuven 2004, 553-572.

Zemer, A., Storage jars in ancient sea trade, Haifa 1977. 